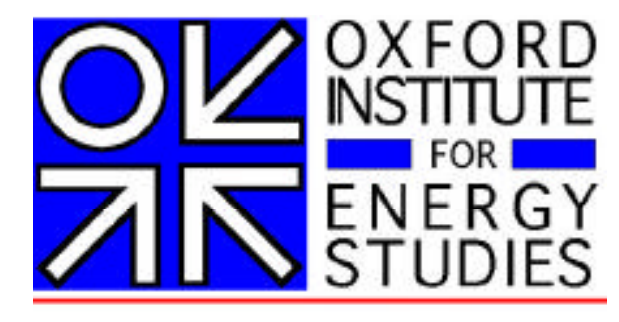

\title{
An Economic Evaluation of Small-scale Distributed Electricity Generation Technologies
}

Christopher Joshi Hansen \& John Bower

Oxford Institute for Energy Studies

$$
\text { EL } 05
$$

October 2003 


\section{An Economic Evaluation of Small-scale Distributed Electricity Generation Technologies}

Christopher Joshi Hansen \& John Bower

Oxford Institute for Energy Studies

57 Woodstock Road

Oxford OX2 6FA

Telephone: $+44(0) 1865311377$

Fax: +44 (0)1865 310527

Email: chris.hansen@ oxfordenergy.org or john.bower@oxfordenergy.org 
The contents of this paper are the authors' sole responsibility. They do not necessarily represent the views of the Oxford Institute for Energy Studies or any of its Members

\title{
Copyright $\odot 2003$
}

\section{Oxford Institute for Energy Studies}

(Registered Charity, No. 286084)

\begin{abstract}
All rights reserved. No part of this publication may be reproduced, stored in a retrieval system, or transmitted in any form or by any means, electronic, mechanical, photocopying, recording, or otherwise, without prior permission of the Oxford Institute for Energy Studies.

This publication is sold subject to the condition that it shall not, by way of trade or otherwise, be lent, resold, hired out, or otherwise circulated without the publisher's consent in any form or binding or cover other than that in which it is published and without similar condition including this condition being imposed on the subsequent purchaser.
\end{abstract}

ISBN 1901795306 


\section{CONTENTS}

ABSTRACT iv

1. EVALUATION OF SMALL-SCALE ELECTRICITY GENERATION ............................ 1

1.1. Small-scale Generation in Rural Areas ................................................................... 2

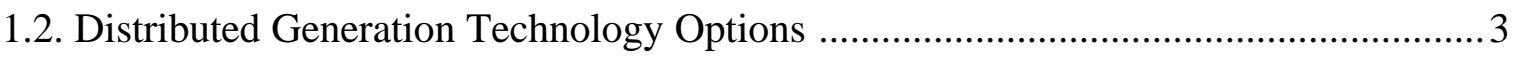

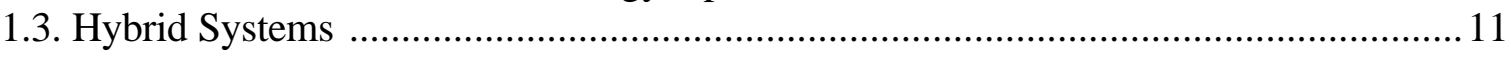

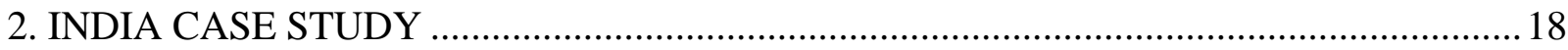

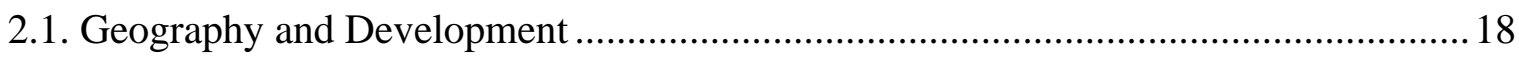

2.2. Electrical Supply Situation and Grid Power Total Costs ..........................................22

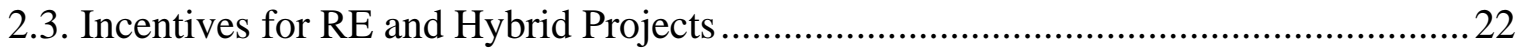

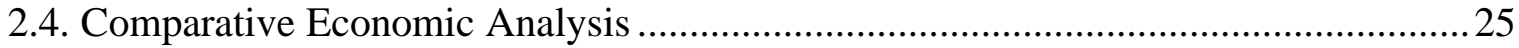

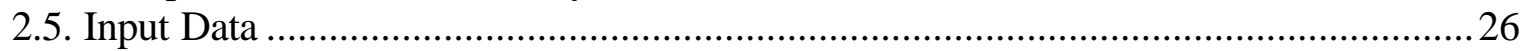

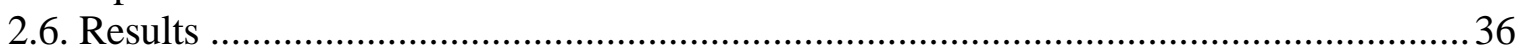

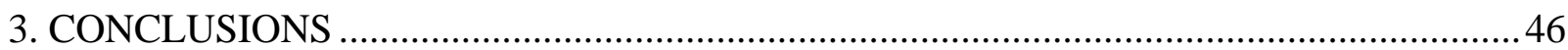

3.1. Additional Benefits of Distributed Generation Systems ............................................ 46

3.2. Barriers to Hybrid Energy Systems in Gujarat........................................................ 49

3.3. Conclusions and Scope for Further Research........................................................50

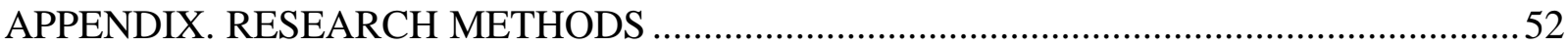

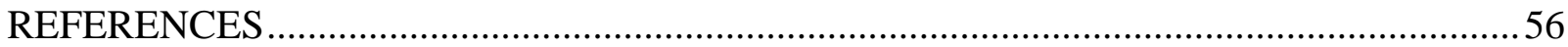




\section{FIGURES}

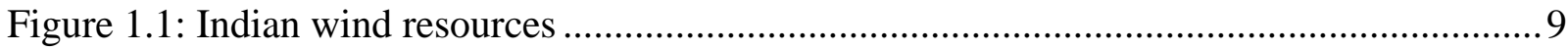

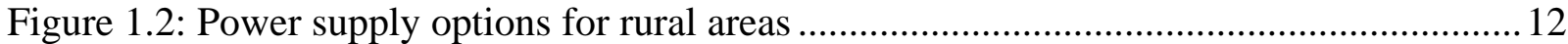

Figure 1.3: Wind-Diesel and PV hybrid system schematic ................................................. 13

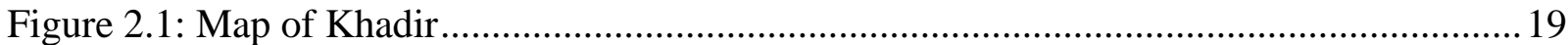

Figure 2.2: Transmission line across the Rann and GEB substation in Balasar.......................22

Figure 2.3: Schematic of the transmission grid in northeastern Kachchh. ...............................23

Figure 2.4: Load profile for PL 1 (large village in Khadir)................................................. 29

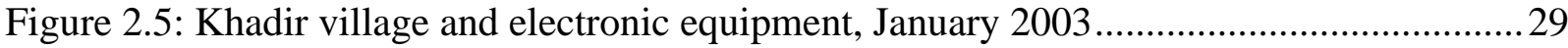

Figure 2.6: Concrete parts factory and $15 \mathrm{~kW}$ diesel genset, Khadir Island, Gujarat................ 30

Figure 2.7: Load profile for PL2 (small concrete parts factory) .............................................. 31

Figure 2.8: Probability distribution of assumed wind resources in Khadir.............................. 32

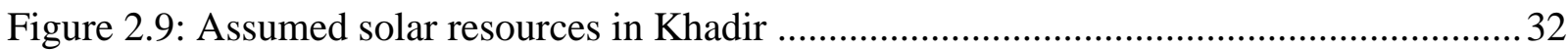

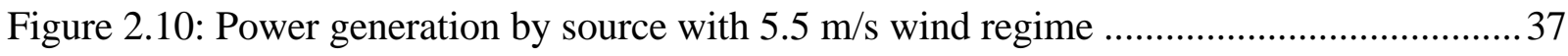

Figure 2.11: Optimal system types, primary load 1 vs. wind speed........................................... 38

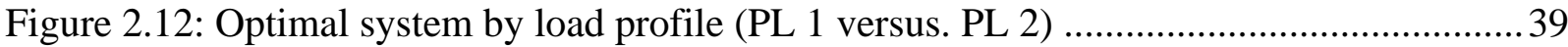

Figure 2.13: Breakeven grid extension distance vs. grid power cost........................................ 39

Figure 2.14: Breakeven grid extension distance vs. grid power cost..................................... 40

Figure 2.15: Cost of energy savings vs. wind speed for four diesel price levels $(\$ / \mathrm{L})$.............42

Figure 2.16: Demand profile for Khadir Village (hour v. $\mathrm{kW}$ ) and demand differentiation...... 43

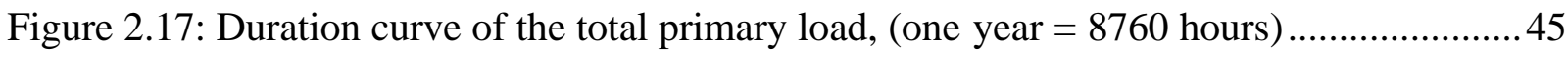

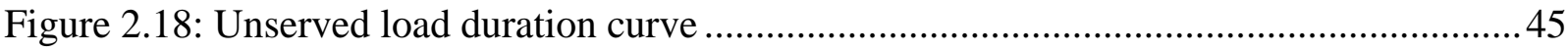

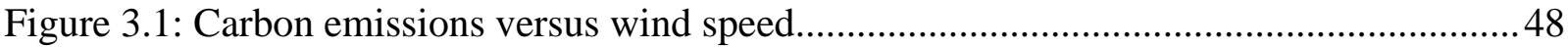

Figure 3.2: Carbon emissions by electricity demand load and wind speed dependence............ 49 


\section{TABLES}

Page

Table 1.1: Distributed generation economic summary for Kachchh District............................ 4

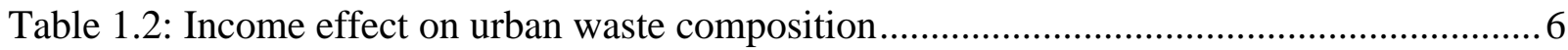

Table 1.3: Selected wind speeds and power at Gujarat monitoring stations, by district............ 11

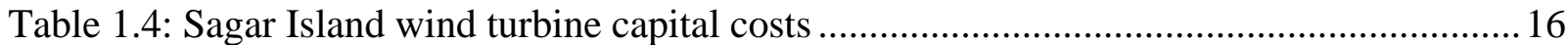

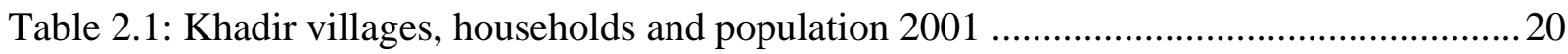

Table 2.2: Khadir villages, number of households by caste/group 2001 ................................21

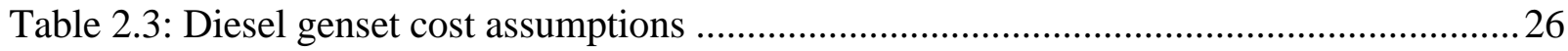

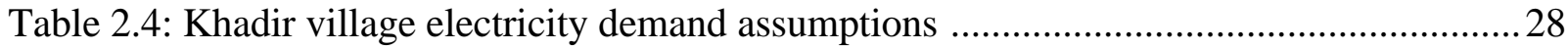

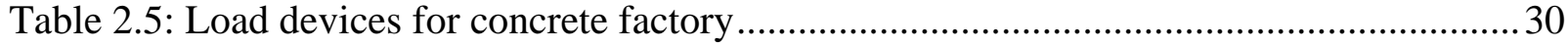

Table 2.6: Wind resource assumptions for Khadir.................................................................... 31

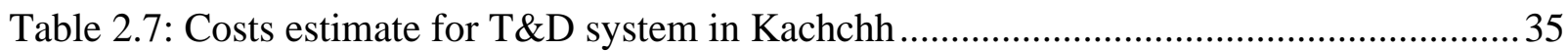

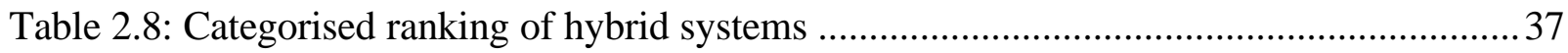

Table 2.9: Fuel price increases and changes in cost of energy............................................. 41 


\begin{abstract}
Numerous renewable and small-scale distributed generation $(D G)$ technologies have now progressed to the stage where their technical feasibility has been proven and full-scale projects have been successfully implemented worldwide. These technologies hold the potential to help provide basic electricity service to the nearly two billion people who are without access to grid-connected power. This paper surveys the available DG technologies and models their economic performance in rural areas of India with particular emphasis on comparing the costs of hybrid DG systems with conventional grid connections for remote rural village-level applications. Modelling inputs are based on demand, fuel availability, costs and local operating conditions found in the Kachchh District of Gujarat, India. Results demonstrate that hybrid power systems can economically provide electricity in nural areas if local energy resources are adequate (e.g. wind, solar, biomass). Additional environmental and economic benefits of hybrid DG are also quantified for the case study area and reveal a 40\% reduction in diesel fuel use compared to diesel genset only systems.
\end{abstract}




\section{EVALUATION OF SMALL-SCALE ELECTRICITY GENERATION}

The provision of reliable electricity supply is vital to economic development in Third World nations. Apart from its important domestic and water pumping applications, electricity is a basic input into post-subsistence economic activity that allows communities to move from primary products into the processing of commodities, production of semi-finished goods and the creation of a manufacturing base. It also increases educational opportunities, improves the quality of life and permits access to information technologies. To the extent that it replaces traditional fuels, electricity improves indoor air quality, in turn leading to improved health and safety. In the long run, reliable electricity supplies connect remote rural communities to the wider manufacturing and service economies of a country.

The provision of electricity in rural areas of developing countries, however, continues to be beset by poor service and inefficient state-run utilities. In India, $40 \%$ of the population still does not have an electric connection, but an array of new energy technologies - called 'distributed generation' - for small-scale electricity generation near the site of use may provide the chance to 'leap frog' to a new stage where ample electricity is available to meet demand, reliably, and in an economically and environmentally sustainable manner. This paper examines the economic viability of distributed generation in rural Gujarat, India, taking into account the economic, engineering and political factors that shape investment decisions.

In order to better understand the potential for DG electricity systems, this paper presents the results of village-level fieldwork carried out in the Kachchh province of Gujarat, both to quantify the problems in the power sector and to form a basis for comparison with hybrid, distributed systems. Section 1 presents an overview of the resources available to supply power on a distributed basis in Gujarat, including: renewable, fossil fuel and hybrid systems that employ some combination of renewables and fossil fuel power, and often include battery storage. In Section 2, a scenario-based approach using the Homer optimisation model from the National Renewable Energy Laboratory (NREL) in Golden, CO USA is used to understand the costs of operating a hybrid power system in Gujarat within the constraints of rural environments. Inputs for the model are both site-specific to the case study in Kachchh, Gujarat and are imputed from existing data, pilot projects, and interviews with industry experts. 


\subsection{Small-scale Generation in Rural Areas}

The energy situation in rural India is characterised by a lack of access to modern fuels (oil, natural gas, propane, etc.), which leads to high use of locally available biomass and animal waste products to meet demand. The Ministry of Power (MoP) (2002) estimates that only 69\% of rural households have power. Many of the homes without a connection are in small hamlets (populations of 50-200) near the main villages, which are not classified as villages in census figures. Without power connections, labour participation rates for women are reduced because of the time needed to collect fuel for cooking and heat. Lack of power also results in high indoor air pollution and high rates of child mortality (Lallament, 2001) and a significant literature exists on the myriad of fuel-related difficulties of rural communities in the developing world (Das and Banerjee, 1995; Yang, 2003; WB, 2001; Bose, 1993).

Access to a reliable supply of energy is one of the driving forces of development for rural communities in developing countries. However, state-owned electricity utilities often struggle to provide reliable service to remote rural areas due to lack of resources. In addition, the crumbling electricity grids cannot cope with existing connections, let alone expand into new areas. Large tariff subsidies have exacerbated the problem by diverting resources from the existing electricity supply industry, while simultaneously reducing the financial incentives for new entrants to produce power. One solution that has been used with some success in both the developed and developing world is to apply small-scale distributed generation (DG) technologies that utilise locally available energy resources.

DG has the advantage of reducing transmission and distribution losses, increasing local employment, utilising local primary energy sources and allowing for incremental expansion of the electricity system with locally raised capital because of its small-scale modularity. However, cost per unit of power is normally higher for DG projects compared to large power plants. Centralised electricity supplies have the advantage of economies of scale that reduce marginal energy costs and long-run average costs of power production, but have to contend with long transmission networks to deliver the power (AGL, 1997). In addition to the technical $\mathrm{T} \& \mathrm{D}$ losses inherent in centralised power delivery models, there is the prevalence of power theft. By contrast, DG projects in operation have shown lower theft levels because ownership, operation and control are developed at the local level so managers and consumers have a vested interest in ensuring the system is viable (AGL, 1997). 
In India, efforts have begun to take advantage of DG. For example, the Ministry of Power has set a goal of electrifying all villages by 2012 under the 'Power for All' program, and as part of this initiative has begun assessing DG technologies to ensure that electricity is available on demand to each household. The Rural Electricity Supply Technology (REST) mission and the creation of a Committee on Distributed Generation inside the MoP form the main thrust of the effort (Chaurey, Ranganathan, and Mohanty, 2002). This DG program must overcome a number of obstacles. Simply picking the correct technology and providing a robust funding mechanism for the capital purchase will not be adequate; arrangements for maintenance, connecting new consumers, providing ongoing service, metering and billing are all needed. A conducive regulatory environment which helps investors deal with the risks inherent in DG schemes is also needed. This environment is lacking in India, where there is no uniform approach to the DG issue (MoP, 2002).

This section builds the argument for using DG in India by summarising the different technology options available for DG and comparing them with central, large power plant costs, including T\&D. Focus is placed on wind-diesel hybrid systems, the technology of choice for the case study area, the rural western district of Kachchh in Gujarat.

\subsection{Distributed Generation Technology Options}

The economics and local suitability of a range of currently available DG technologies to Kachchh are summarised in Table 1.1. Only those technologies that are technically feasible in Kachchh are included on the short list of three suitable candidates for further economic analysis in Section 2, biomass is then added for completeness because of its wide availability in other parts of India. Technologies that require unavailable local energy resources, even if they offer excellent economic potential, will always be infeasible. A short description of each technology and the reason for their inclusion or exclusion from the shortlist are given in more detail below. 
Table 1.1: Distributed generation economic summary for Kachchh District

\begin{tabular}{|l|rrrr|r|r|}
\hline \multicolumn{1}{|c|}{ Technology } & $\begin{array}{r}\text { Efficiency } \\
(\%)\end{array}$ & $\begin{array}{c}\text { Capital Cost } \\
(\$ / \mathrm{kW})\end{array}$ & $\begin{array}{c}\text { O\&M Cost } \\
(\$ / \mathrm{kWh})\end{array}$ & $\begin{array}{c}\text { Electricity Cost } \\
(\$ / \mathrm{kWh})\end{array}$ & $\begin{array}{c}\text { Technology } \\
\text { Status }\end{array}$ & $\begin{array}{c}\text { Suitability for } \\
\text { rural Kutch }\end{array}$ \\
\hline \hline Mictroturbines & $27-32$ & 500 & 0.005 & $0.06-0.08$ & Commercial & No \\
Fuel Cells & $40-60$ & 3000 & 0.0017 & $0.06-0.08$ & Pre-Commercial & No \\
Micro-hydro & 80 & 1500 & 0.001 & $0.09-0.15$ & Commercial & No \\
Biomass & 25 & $800-1500$ & $0.01-0.12$ & $0.07-0.14$ & Commercial & No \\
\hline Photovoltaics & $6-19$ & $3000-6000$ & 0.001 & $0.18-0.20$ & Commercial & Yes \\
\hline Diesel & $15-25$ & $150-500$ & 0.01 & $0.07-0.11$ & Commercial & Yes \\
\hline Wind Turbines & 25 & $850-1200$ & 0.01 & $0.03-0.07$ & Commercial & Yes \\
\hline
\end{tabular}

Source: (AGL, 1997; EIA, 2002; Gregory et al., 1997; Morris, 1998; Petrie, Willis, and Takahashi, 2000; Ravindranath and Hall, 1995; UN, 1989)

\subsubsection{Fuel Cells}

Fuel cells convert hydrogen and oxygen into electricity, heat and water; and are an old technology that has been given renewed attention in the last two decades. The development of large-scale (1 MW plus) and small fuel cells $(\sim 50 \mathrm{~kW})$ units has received heavy investment by governments and corporations in the developed world. High operating efficiencies, in the range $40-80 \%$, depending on the configuration, can be achieved, especially if the waste heat is utilised (Petrie, Willis, and Takahashi, 2000). However, the need for a high quality fuel supply, (e.g. natural gas), to produce the hydrogen limits their applicability in rural Kachchh where no regular pipeline gas supplies exist. Fuel cells remain a pre-commercial technology, and under even aggressive assumptions have capital costs that are too expensive for village electrification. Local maintenance capability is also non-existent. For these reasons, fuel cell technology is not considered further for the case study.

\subsubsection{Solar Photovoltaics}

The use of solar photovoltaics and solar thermal conversion technology was evaluated for Gujarat and found to be expensive for small- and medium-scale power production. Capital costs of $\$ 3,000-6,000 / \mathrm{kW}$ for solar technology (Bakos and Soursos, 2002; Barley, Meares, and Flowers, 1998) mean it is applicable only in serving small or remote loads. High capital costs, and a lack of local capacity to maintain the systems have also limited the opportunities to expand solar panel use. However, solar home systems (SHS) and small solar panel systems have been used in niche applications (Malaviya and Ranade, 1997; Ibrahim et al., 2002), especially projects that require only lighting loads of 20-100 W. SHS systems do not have sufficient capacity to serve small rural industries and groups of villages with $50-100 \mathrm{~kW}$ 
demand profiles. However, for small, single village applications hybrid PV schemes may play an economical role, particularly when used in combination with other technologies in a hybrid scheme and when adequate power storage is available. PV in hybrid systems can be the most cost-effective solution in some situations, such as when the costs of diesel fuel delivery increase fuel prices by 15-50\% (Schmid and Hoffmann, 2003). It may be that PV has applicability in rural Kachchh and its feasibility will therefore be tested in Section 2.

\subsubsection{Microturbines}

Microturbines operate on the same principle as gas turbines used in centralised power plants, by converting gaseuos fuels into electricity using the expansion of hot combustion products. The advantage of the technology is that it is highly efficient compared to diesel gensets when the waste heat is used. Microturbines are available in many different sizes, from $75 \mathrm{~kW}-1 \mathrm{MW}$. The disadvantage of microturbines is the higher relative capital costs, approximately $\$ 500 / \mathrm{kW}$ compared to $\$ 200-400 / \mathrm{kW}$ for diesel (Petrie, Willis, and Takahashi, 2000). Microturbines also require a reliable and affordable fuel supply, preferably clean pipeline natural gas, which is not readily available in Kachchh. In addition, there is little experience in rural India with microturbines and no maintenance infrastructure exists. For these reasons they are not considered further.

\subsubsection{Biomass \& Biogas}

The use of biomass for energy needs in rural areas in India has been well documented (Ravindranath and Hall, 1995; AGL, 1997) and many opportunities exist for further exploitation, depending on the local resources. Biomass energy systems take advantage of farm, manure and plant wastes which are normally readily available in rural areas, and either burn them for power or gasify them for fuel or electricity. The technology has been well tested and is technically feasible, but can require high levels of maintenance. For Kachchh, the relatively scarce biomass supplies and the need to increase food production, preclude the dedicated use of land only for biomass production (Sudha and Ravindranath, 1999). The need to use farm wastes as fertilisers also limits the prospects of a biomass energy program in the district. The technology is therefore not considered further for Kachchh, but is likely to be a viable choice in other areas of India with adequate biomass resources and is included in the modelling for comparison. 


\subsubsection{Municipal Waste Incineration and Landfill Gas}

Municipal solid waste is primarily the responsibility of local governments in India, and it remains a labour-intensive activity from initial collection to final disposal. However, even with the low cost of labour, waste management has not been a high priority for many municipal governments and little assistance has been available from state and local institutions. In a majority of Indian urban centres, the most common method of disposing of waste is to dump it in illegal, informal, dumps on the outskirts of the city (van Beukering et al., 1999). Simple landfill techniques, such as compaction, levelling of waste and the application of a final cover of soil, are rarely used. More advanced methods, such as leachate controls, installation of ground water contamination monitoring, and gas collection systems are even more rare. The national average for waste collection in India, as measured by the National Institute of Urban Affairs, is a relatively low $72.5 \%$ as compared to near $100 \%$ in OECD countries (Gupta et al., 1998).

Income levels also have a direct effect on both the amount of urban waste produced per person, as well as its composition. Urban waste can be categorised into combustibles, recyclables, organics, and inorganics. Combustibles typically consist of paper, cardboard, wood, and plastics. Recyclables include glass and metals, and in some developing countries, paper products that are removed by garbage scavengers. Food scraps, food waste, and yard waste make up the organics. Non-wood building materials, such as concrete, coal ash and street dirt, account for most of the inorganics in the waste stream.

The composition of waste dictates the application of energy technology. Higher income countries tend to have greater levels of paper and plastic combustibles, while developing countries' waste has a higher concentration of organic foodstuffs and inorganic building materials. This distributional effect is illustrated in Table 1.2.

Table 1.2: Income effect on urban waste composition

\begin{tabular}{|l|l|l|l|l|}
\hline Country Income Level & $\begin{array}{l}\% \\
\text { Combustible }\end{array}$ & $\begin{array}{l}\% \\
\text { Recyclable }\end{array}$ & $\begin{array}{l}\% \\
\text { Organic }\end{array}$ & $\begin{array}{l}\% \\
\text { Inorganic }\end{array}$ \\
\hline High (US, Europe, Japan) & $45-55$ & 10 & $10-30$ & $10-30$ \\
\hline Middle (Thailand, Mexico) & $20-40$ & $8-10$ & $40-55$ & $3-10$ \\
\hline Low (Peru, India) & $10-30$ & $2-3$ & $25-55$ & $35-45$ \\
\hline
\end{tabular}

Source: (Ashworth, 1996) 
Indian waste has low calorie content for burning, thus the only way to capture organic content energy is to gasify. Waste in standard landfills, defined as lined and soil-capped installations, undergoes slow rates of anaerobic decomposition, which produces landfill gas (LFG) consisting of $40 \%$ to $50 \%$ methane that can be captured using a gas collection system and used for small-scale electricity generation or heating. However, well-organised waste collection systems and landfill maintenance are lacking in rural Kachchh, and the low waste collection rates do not make this a viable option for the area.

\subsubsection{Diesel Turbines}

Diesel gensets are the most commonly used system for DG and back-up power applications in India. With relatively low up-front capital costs, easy installation, modularity, readily available technology, and a good maintenance infrastructure already in place, they are a viable option for many remote rural locations. Diesel fuel delivery systems are well developed across India because many irrigators use diesel gensets directly for water pumping, and small businesses and homes depend on gensets for power when the grid fails. However, high air and noise pollution, expensive fuel and constant maintenance costs for gensets translate into high unit power costs for rural users. Nevertheless, they are a reliable and technically feasible DG solution for Kachchh, and their economics compared with the alternatives will be examined in more detail in Section 2.

\subsubsection{Mini-hydroelectric}

Small-scale hydroelectric units have been used successfully in many parts of South Asia as a local energy solution (Gunaratne, 2002; WEC, 2000). The advantages of small hydro projects include: zero emissions, use of well-known and proven technology and the employment of local labour in their construction and maintenance (UN, 1989). However, such projects require a steady flow of surface water, which is almost totally absent in northern Kachchh (Mehta, 2001). Therefore this option is not considered further.

\subsubsection{Wind Turbines}

Worldwide, windpower has achieved rapidly increasing levels of technological and economic maturity in the past two decades. Decreasing capital costs, a variety of production, capital and tax subsidies and more robust wind turbines have increased the potential opportunity for windpower to penetrate in both grid-connected and remote generation applications. In 1999, 
$12 \mathrm{GW}$ of grid-connected windpower was installed worldwide, a 550\% growth from 1990 levels (McGowan and Connors, 2000); however, a variety of institutional and technological problems are hindering progress. First, high costs of importing wind turbine technology and engineering expertise have also slowed down investment in developing countries. Second, wind resources are poorly documented for specific locations and for seasonal changes in developing nations, and such documentation must be completed before investment can take place. In response, India has undertaken a massive wind measurement program and encouraged investment in local turbine manufacture to overcome these hurdles.

India's installed capacity in wind energy stands at $1736 \mathrm{MW}$ at the end of February 2003 (CECL, 2003), an increase of $277 \mathrm{MW}$ in 2001-02 and is planned to rise by $250 \mathrm{MW}$ to 300 MW annually in the next three years. However, frequent changes in state policies have been an impediment to growth (PTIa, 2002). Rajsekhar, et al (1999) argue that state and centre incentives need to be retooled to continue to spur investment, as they have relied only on capital incentives and tax advantages up to this point. For progress to continue, they assert that production incentives and a clearer relationship with the SEBs are needed (Rajsekhar, Van Hulle, and Jansen, 1999).

A good local production base for wind turbines now exists in India, with most of the leading, state-of-the art international models manufactured and installed by local companies (WEC, 2000). Suzlon Energy Limited is the largest fully-integrated windpower company in India and the manufacturer for the $240 \mathrm{MW}$ Maharashtra project (AWEA, 2002). Wind turbines made in India, are also being exported, as evidenced by the Pune-based, Suzlon Energy's recent agreement to export $100 \mathrm{MW}$ turbines to China and the U.S. The first project is a $\$ 22$ million order to install $24 \mathrm{MW}$ of turbines in Minnesota during the winter of 2002-03. The project is the first wind energy project export by an Indian company to the U.S. (PTIa, 2003). Suzlon is ranked the ninth largest wind energy turbine manufacturer in the world, and plans to export $1500 \mathrm{MW}$ of turbines over a period of a few years. It currently has the capacity to produce 750 $\mathrm{kW}$ machines and plans to expand into the 1.5 MW range. Suzlon is also the first developing world wind company to set up a 100\%-owned subsidiary in the U.S., Suzlon Wind Energy Corporation, and is negotiating large projects in California and Texas (PTIa, 2002).

The Gujarat Energy Development Agency (GEDA) estimates that local manufacture of wind turbines has helped to reduce both costs and the need for imports. Large-scale wind farms are 
now planned on a Rs 40 million/MW basis (or approximately $\$ 833 / \mathrm{kW}$ ), which is $10 \%$ less than wind farms that use imported machines (Patil, 2003). Two of the world's leading wind turbine makers, Danish Vestas and NEG Micon, are both expecting strong growth in India, the fifth biggest windpower market in the world. The Vestas India joint venture, led by Rakesh Bakshi, expects 6000-7000 MW of windpower to be installed in India over the coming 10 years. Vestas' biggest turbine in India in 2002 was $500 \mathrm{~kW}$ but it plans to add an $850 \mathrm{~kW}$ turbine in 2003, and in two years move towards 2.0 MW turbines. NEG has introduced a 950 $\mathrm{kW}$ turbine to the Indian market and plans to launch its $1.5 \mathrm{MW}$ next year, with $100 \%$ Indian manufacture at its new assembling plant in India by 2003 (Reuters, 2002).

India has implemented a major wind resource assessment program comprised of wind monitoring, wind mapping and complex terrain projects, which cover 800 stations in 24 states. Wind surveys have identified specific windpower production locations, and in 2000 demarcated 177 sites in 13 states with the potential for about 45,000 MWof installed capacity (WEC, 2000). Figure 1.1 shows the aggregate results of this effort.

Figure 1.1: Indian wind resources

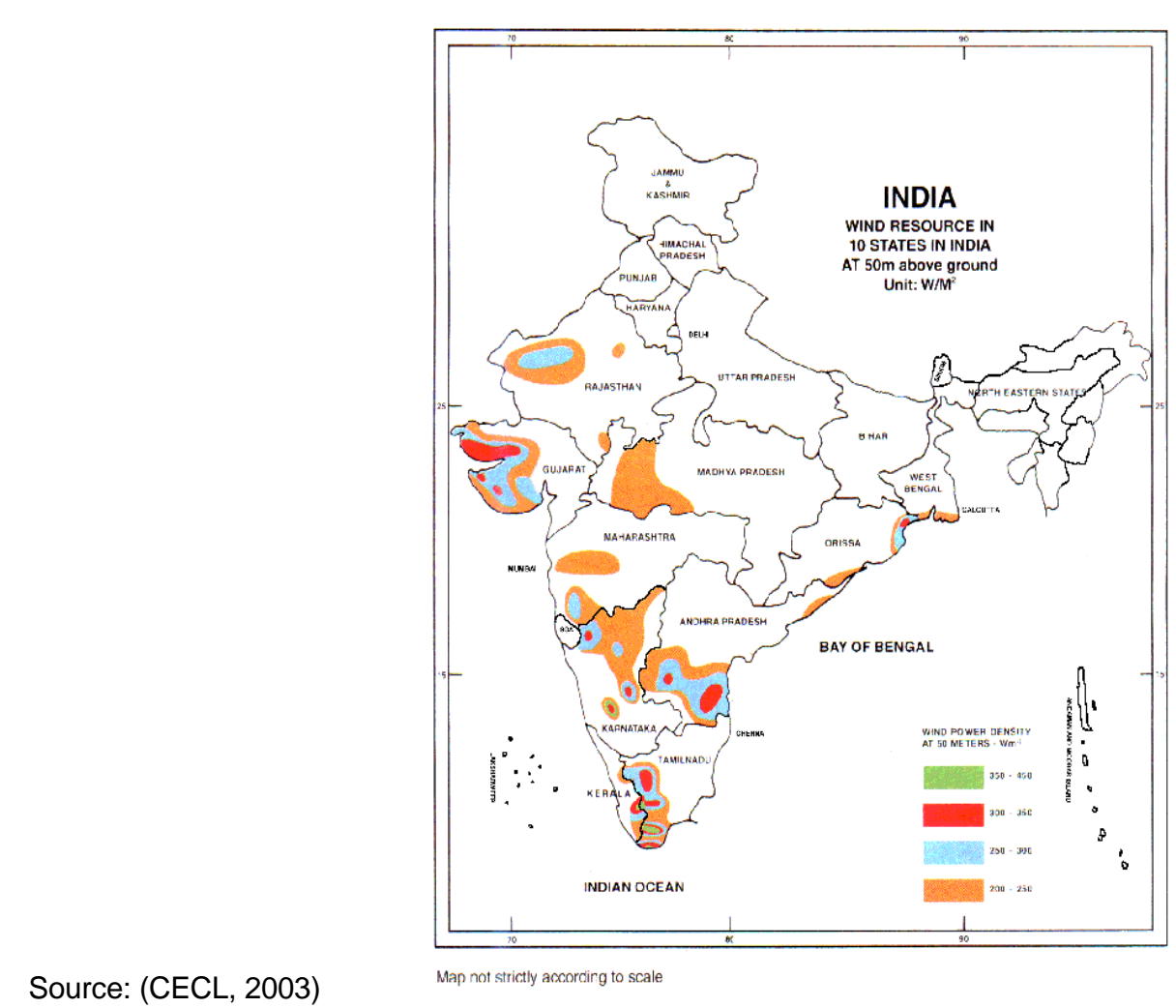

The Wind Energy Survey Program undertaken by the Minisry of Non-conventiaonal Energy Sources (MNES) during the 1980s and 1990s has identified several sites in the Saurashtra and 
Kachchh regions of Gujarat that have adequate winds for wind turbines. The total windpower potential of the state is on the order of $5000 \mathrm{MW}$, or approximately $10 \%$ of the total potential in India, with Tamil Nadu and Karnataka the two most significant states for windpower (Joshi, 1997). GEDA estimates the potential at $1000 \mathrm{MW}$ for grid-connected wind farms in Gujarat, and has a five-year policy goal of reaching 200-250 MW installed capacity (Patil, 2003).

A rule of thumb for wind developers is to look for sites with at least $18 \mathrm{kmph}$ or 5 meters/second $(\mathrm{m} / \mathrm{s})$ annual mean wind speeds and power densities of $140 \mathrm{~W} / \mathrm{m}^{2}$ at $20 \mathrm{~m}$. The percentage of power during the windiest months, May to September in western India, is also an important criterion, as it directly affects the capacity utilisation factor (CUF). ${ }^{1}$ Wind farm performance results from the early 1990s in Gujarat show very low CUF, 10-14\%, due to a variety of technical and operational problems, which include:

i. Unsuitability of turbine designs to Indian conditions, e.g. lower wind speeds and corrosive environment;

ii. Incompatibility with the grid;

iii. Frequent tripping of the generator due to large voltage and frequency fluctuations;

iv. Failure of lightening arrestors;

v. Line faults in power evacuation equipment; and

vi. Cyclones and extreme weather events (e.g. $27 \mathrm{MW}$ of wind turbines where damaged during the 1998 cyclone season).

The coastal wind farms have performed better than the inland units, with CUFs of 16-17\%, compared with $10-11 \%$ for the $65 \mathrm{MW}$ of inland capacity. GEDA attributes the low utilisation factor for inland units to poor siting and a mismatch between the initial mapping of the prime wind resource on the crests of hilly ranges and the eventual siting of the turbines at lower elevations (Patil, 2003).

After a lull in investment, the number of large-scale wind projects may be rebounding in Gujarat and demonstrated by the $100 \mathrm{MW}$ of applications GEDA received from September 2002 to January 2003. One factor that should support the long-term growth of windpower in Gujarat is the local capacity to build, operate and maintain wind turbine infrastructure. Several

\footnotetext{
${ }^{1}$ The CUF is defined as the total energy generated by wind turbine divided by product of the turbine rating and the number of hours in the time period being considered, normally one year. For example, a $50 \mathrm{~kW}$ wind turbine would have a $10 \%$ CUF if it produced at half power for $20 \%$ of the year.
} 
local companies have established themselves in Gujarat to service turbines, including Simms Engineering and Kintech Systems.

In Gujarat, scores of wind test stations have been used to estimate the wind potential in different parts of the state. Table 1.3 shows selected results from the field-testing stations operated by the government. The high power densities and wind speeds at $50 \mathrm{~m}$ means that some areas of Kachchh are well suited for windpower; and the stations in bold in the table form the data baseline for the Kachchh analysis in Section 2.

Table 1.3: Selected wind speeds and power at Gujarat monitoring stations, by district

\begin{tabular}{|c|c|c|c|c|c|c|}
\hline \multirow{2}{*}{ Station } & \multirow{2}{*}{ District } & \multirow{2}{*}{$\begin{array}{c}\text { Elevation } \\
\text { m.a.s.l. }\end{array}$} & \multicolumn{2}{|c|}{$\begin{array}{c}\text { Mean Annual Wind } \\
(\mathrm{m} / \mathrm{s})\end{array}$} & \multicolumn{2}{|c|}{$\begin{array}{c}\text { Mean Annual Wind } \\
\left(\mathrm{W} / \mathbf{m}^{2}\right)\end{array}$} \\
\hline & & & At Mast & $\begin{array}{c}\text { At } \\
30 \mathrm{~m} \\
\end{array}$ & At Mast & $\begin{array}{c}\text { At } \\
\mathbf{5 0 ~} \mathbf{m} \\
\end{array}$ \\
\hline Rojmal 2 & Bhavnagar & 140 & 5.33 & 5.61 & 129 & 317 \\
\hline Sanador & Bhavnagar & 80 & 5.64 & 5.97 & 197.1 & 373 \\
\hline Kalyanpur & Jamnagar & 92 & 5.49 & 5.85 & 207.5 & 327 \\
\hline Navadra 1 & Jamnagar & 24 & 5.57 & 5.89 & 182.7 & 297 \\
\hline Suvarda & Jamnagar & 90 & 6.14 & 6.58 & 166 & 444 \\
\hline Jamanvada & \begin{tabular}{|l} 
Junagarh \\
\end{tabular} & 57 & 5.56 & 5.86 & 149.4 & 299 \\
\hline$\overline{\text { Adesar }}$ & Kutch & 23 & 5.31 & 5.58 & 93.4 & 307 \\
\hline Bayath & Kutch & & 5.97 & 6.14 & 118.2 & 300 \\
\hline Kukma & Kutch & 205 & 4.86 & 5.67 & 149.6 & 239 \\
\hline Motisindholi & Kutch & 5 & 5.42 & 5.92 & 117.9 & 311 \\
\hline Mundra & Kutch & 4 & 5.78 & 6.22 & 167.5 & 303 \\
\hline Poladiya & Kutch & 120 & 5.56 & 6.08 & 177 & 278 \\
\hline Surajbari & Kutch & 9 & 5.39 & 5.72 & 184.2 & 243 \\
\hline Dhank-II & Rajkot & 208 & 5.66 & 6.11 & 327 & 367 \\
\hline
\end{tabular}

Note - mast height equals $20 \mathrm{~m}$

Source: (CECL, 2003)

\subsection{Hybrid Systems}

To provide energy services to remote areas, three options are available:

Increase central power plant output;

ii. fossil fuel-fired distribute generation (e.g. diesel gensets); and

iii. Renewable power generation.

Taking each one separately, several drawbacks are apparent, as shown in Figure 1.2. One possible solution that helps to cancel out the drawbacks of diesel and renewable energy 
technologies is to employ both types in combination, with the objective of exploiting their operating characteristics to minimise costs and maximise availability. The three feasible Kachchh DG technologies identified in the previous section may therefore complement each other when used in combination.

Figure 1.2: Power supply options for rural areas

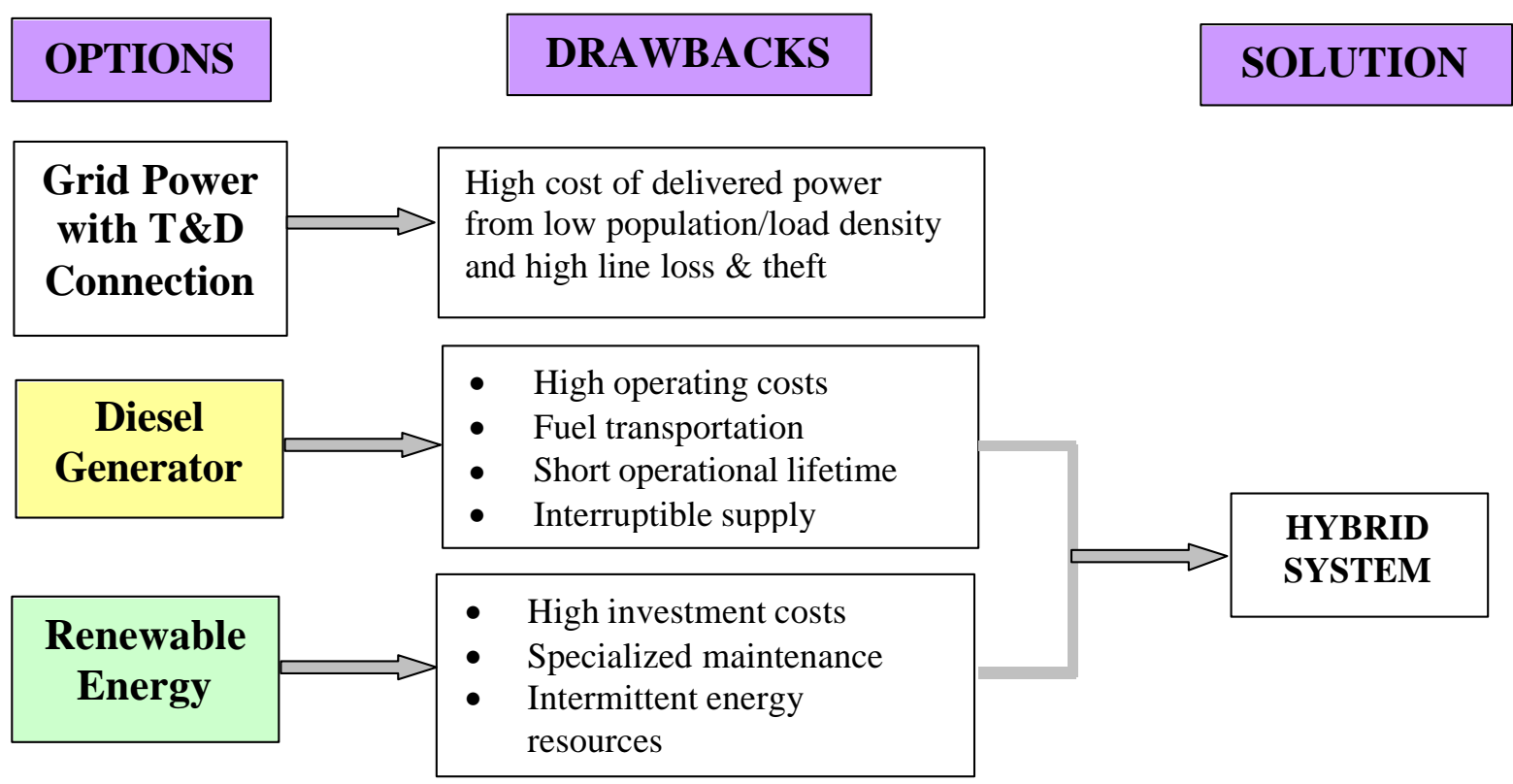

\subsubsection{Hybrid System Description}

A hybrid energy system is defined as an installation that uses two or more generation technologies in concert. The goal of using multiple technologies is to take advantage of the best operational characteristics of each system and create synergy in their combination. For example, the costs associated with the diesel gensets are dominated by the costs of fuel delivery and the on-going maintenance. This contrasts with the wind turbines where costs are dominated by the upfront capital investment, but have low maintenance requirements. Further, a diesel genset provides good reliability and when combined with wind or PV, the renewables reduce fuel consumption and emissions from the diesel (Drouilhet, 2001).

Hybrid systems for rural electrification can be configured in three different ways: grid connected, off-grid with distribution system, and off-grid for direct supply. The first configuration has the advantage of being able to rely on the grid if the hybrid system has problems. Likewise, the grid is strengthened by the power supply near the end of its reach, 
thus boosting voltage and reducing power cuts. For off-grid configurations, the hybrid can either be connected to many load centres, 200 households in a group of villages for example, or can act as a source of supply for one or two loads, thus obviating the need for a distribution system. A non-connected off-grid system is usually used to charge batteries or supply power to a small rural industry, such as a grain milling operation.

The components of the hybrid system modelled in Section 2 include wind turbines, diesel gensets, inverters, power control equipment (e.g rectifiers, inverters, switches), batteries and a dump load. Figure 1.3 displays all the modelled components and how they are connected in schematic graphical form.

Figure 1.3: Wind-Diesel and PV hybrid system schematic

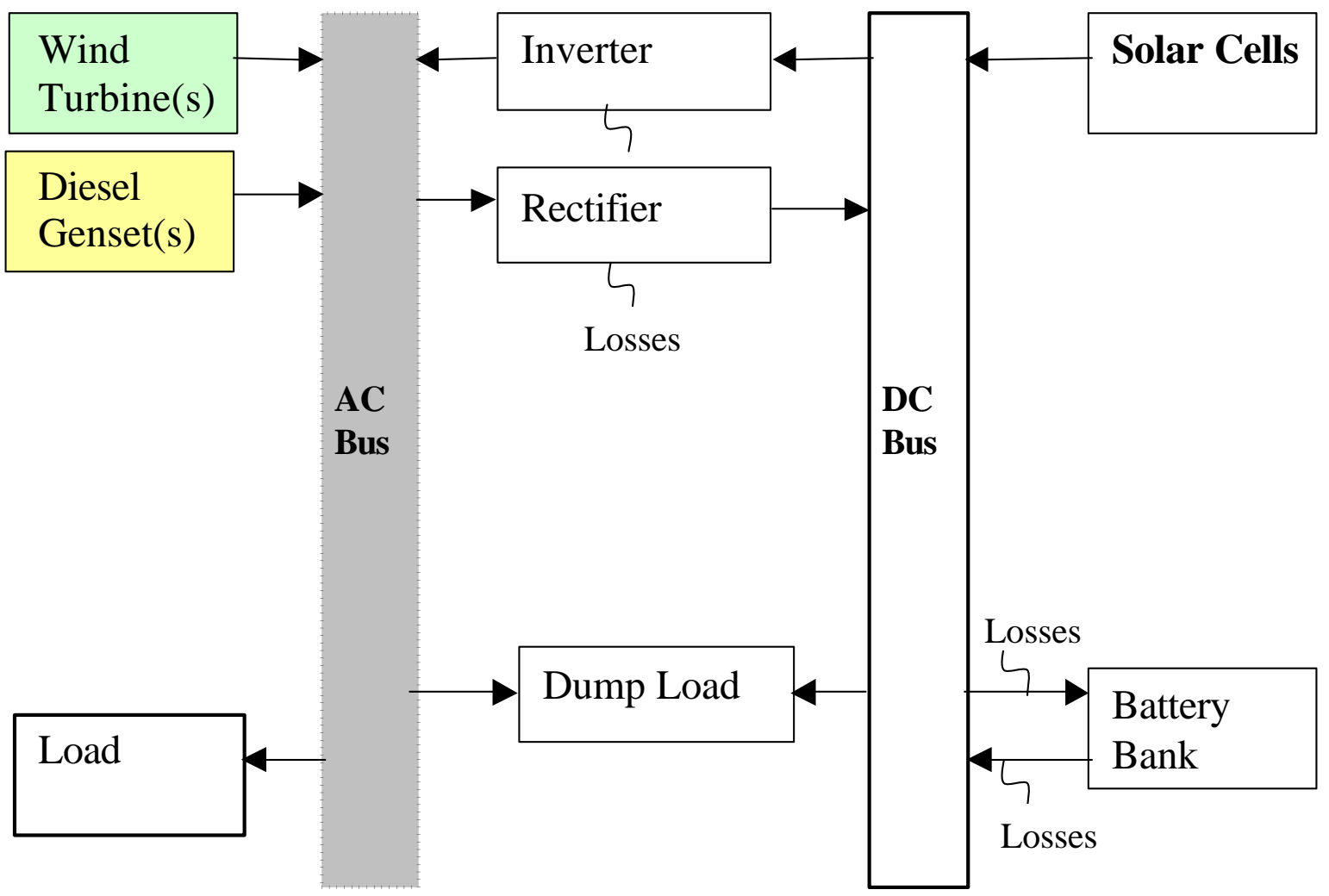

Source: adapted from (McGowan and Manwell, 2000)

The turbines and diesel gensets feed power into the AC system, which is connected to the consumer load. If the power supplied is above the load demand at any given time, it is sent through the rectifier and changed to DC for storage in the battery bank. Alternatively, the 
excess power can be sent to the dump load. ${ }^{2}$ When the wind speed or sun intensity is low, the battery bank sends stored power through the inverter to the AC side, and on to the consumers. Each trip from AC to DC incurs losses, as does the battery storage process; industrial batteries typically have a round trip efficiency of $80 \%$, or $20 \%$ losses.

To maximise the use of the renewable energy (RE) devices and serve the load most efficiently, three different dispatch strategies can be employed. The first is a 'series' hybrid system in which the diesel and RE source run to charge the battery and all power for the load is drawn from the battery bank. The second type of hybrid system is the 'switched' configuration, where the diesel and RE sources are fed directly to the load and excess power is funnelled to the batteries allowing the diesel to be shut off during low load periods. System integrated batteries are also used to supply power for short durations to compensate for the power output fluctuations of the wind turbine(s) and to avoid brief starts of the diesel generator(s). If the batteries run low, the diesel generator starts up to feed the load and recharges the batteries. One aim of this 'load-following' control strategy is to operate the diesel generator primarily when a high fraction of its rated capacity is needed, as this is the most fuel-efficient, and therefore cost-efficient, mode of operation (Ackermann, 2002).

The third type of system configuration is run without batteries and uses the RE source for power whenever it is available and relies on the diesel to make up the difference (Barely, 1996; Rajsekhar and Mathur, 1999). Which of these strategies proves to be the most effective depends on the local conditions and demand profile, and all three are tested in the model, presented in Section 2.

The economic feasibility of a hybrid system is determined by local conditions and resource availability. Wind-diesel hybrid system economics depend on six key variables:

i. Available wind resources;

ii. Delivered price of diesel fuel;

iii. Capital costs of the wind turbine, genset and auxiliary equipment;

iv. Life-cycle operating costs, including maintenance;

v. Value of secondary load; and

vi. Reliability of demand and revenue collection.

\footnotetext{
${ }^{2}$ The dump load can be put to productive use, e.g. an ice machine for packing food products, or a non-useful
} device, e.g. a resistance heater, that 'soaks up' extra power created by the wind/PV devices so as to prevent 
Each of these variables will be examined and tested for sensitivity in Section 2. Two initial condition factors that bode well for hybrid systems in Gujarat are that a dealer/service network for diesel generators already exists, and this infrastructure could be leveraged to provide service for hybrid systems (Rajsekhar and Mathur, 1999). Second, the wind maintenance sector is also well developed, as it now supports $150 \mathrm{MW}$ of grid-installed capacity.

\subsubsection{Hybrid System Project Experience}

Hybrid systems with wind, PV and diesel have been used in hundreds of locations around the world, with commercial and pilot projects implemented in Chile, Philippines, Mexico, USA, Indonesia, Spain, Brazil and India (Flowers et al., 2000; Morris, 1998; Lew et al., 1996; Bhave, 1999; Schmid and Hoffmann, 2003) Hybrids have also received extensive testing through the National Renewable Energy Laboratory (NREL) in Golden, Colorado (Bialasiewicz et al., 1998; Drouilhet, 2001; Baring-Gould et al., 2001). The operational experiences of two functioning wind-diesel projects, the first wind-diesel hybrid project in India, at Sagar Island, and a project in the Canary Islands are described.

\section{$\underline{\text { Sagar Island Project }}$}

The Sagar Island wind-diesel hybrid project was the first of its kind in India and was designed to replace the existing system of diesel-only generation. Sagar Island is not connected to the T\&D system on the mainland of West Bengal and has relied on diesel gensets for all electricity supplies. The high costs of importing fuel and the need to expand service to a larger swath of the island led the West Bengal government to explore hybrid systems as a possible solution.

Sponsored by the WBREDA, the project's first phase commissioned two 50kW AOC 15/50 turbines in April 2002. The project costs were approximately $\$ 77,000$ per turbine for capital costs and $\$ 30,000$ per turbine for installation and commissioning expenses. The total planned costs for phases 1 and 2 with a total of 10 turbines installed, is estimated at just under $\$ 1.3$ million. Table 1.4 details the costs for the turbines.

system overload. 
The project uses new diesel generators and to simplify the electronics, sets the whole wind farm at 415 Volts with no step-up transformers at the wind turbines. The power evacuation is through a single $315 \mathrm{kVA}$ transformer at 11,000 Volts (Imhoff, 2003). To reduce costs, up to $20 \%$ of the demand can be shed, effectively making it interruptible supply; thus no power storage equipment was installed and all power is immediately used to meet demand. The hybrid configuration has a dump load of $50 \mathrm{~kW}$, which is the equivalent of one wind turbine's capacity, in case supply exceeds demand. The initial commissioning (phase 1) installed a resistive heater for the dump load, but plans have been developed to switch to an icemaker, which can be used by local business for income generation in phase 2 of the project. (Natarajan, 2002).

Table 1.4: Sagar Island wind turbine capital costs

\begin{tabular}{|l|r|r|r|r|r|}
\hline \multicolumn{1}{|c|}{ Items } & Qty. & \multicolumn{1}{c|}{$\begin{array}{c}\text { per unit } \\
\text { US } \$\end{array}$} & \multicolumn{1}{c|}{$\begin{array}{r}\text { per unit } \\
\text { Rs }\end{array}$} & $\begin{array}{r}\text { Total Price } \\
\text { Rs }\end{array}$ & $\begin{array}{c}\text { Total Price } \\
\text { US\$ } \$\end{array}$ \\
\hline \hline Windturbines: & & & & & \\
$\quad$ AOC 15/50 & 10 & 64,688 & $3,032,550$ & $30,325,500$ & 645,223 \\
safety cables & 10 & 738 & 34,574 & 345,740 & 7,356 \\
Parts of Indian origin: & & & & & 0 \\
$\quad$ Tower & 10 & 6,875 & 322,300 & $3,223,000$ & 68,574 \\
Assembly and Testing of the AOC 15/50 & 10 & 3,040 & 142,500 & $1,425,000$ & 30,319 \\
Tilt down interface & 10 & 1,219 & 57,135 & 571,350 & 12,156 \\
\hline TOTAL & 10 & $\mathbf{7 6 , 5 5 8}$ & $3,589,059$ & $35,890,590$ & 763,630 \\
\hline
\end{tabular}

Note: 1 US\$ = Rs 47

Source: (Imhoff, 2003)

Operationally, because of the many unknown factors involved in a first time project, the costs and time for implementation have been higher than planned (e.g. one year planned, three years required) and would likely be reduced for subsequent efforts (Imhoff, 2003). The Sagar Island project also suffered from a significant amount of political pressure, which drove up costs. The West Bengal authorities under the current five-year plan prescribed that Sagar Island be electrified, leading to an early commissioning of the project even before there were adequate loads to test the system. The two $50 \mathrm{~kW}$ wind turbines that were installed as part of phase 1 have performed well, but the wind resources available were highly seasonal, going from $6 \mathrm{~m} / \mathrm{s}$ average in February-May to a low of $3 \mathrm{~m} / \mathrm{s}$ in September. The low winds in the off-season have caused low turbine outputs, with load factors below the $20 \%$ range.

The parts of the village that have been electrified receive a prescribed level of service: four hours per day with a load limit of two light points (15 W compact fluorescence light bulbs) and 
one plug point, for a maximum power draw of $100 \mathrm{~W}$. Customers are charged Rs 500 for a connection and Rs 75 per month in energy charges (approx. Rs 7/kWh with average use). For customers desiring a higher level of service of $250 \mathrm{~W}$, a Rs 1500 connection fee is charged and energy tariffs adjusted accordingly (Natarajan, 2002). To increase the local employment creation from the project, local firms are given the distribution installation contracts. The funding agency project manager, Dr. Natarajan (2002) of the India-Canada Environmental Facility commented that the capital costs for this type of project would have to be subsidised because poor customers are only able to pay running costs and that 'willingness to pay' surveys for rural areas are typically too optimistic.

\section{Canary Island Project}

The Canary Island project was implemented in the small coastal fishing village of Puerto de la Cruz on the island of Fuerteventura. The village is an isolated community with no local water or power resources, and a permanent population of 60 persons, with 450 residents in the summer, and an additional 500 tourists per day in high season. The $\$ 1.4$ million project was sponsored under the VALOREN Program of the European Union (50\%) with the rest of the funds coming from the local government and the Spanish Renewable Energy Institute (IER). The aim was to minimise the use of the diesel gensets, which were responsible for all power generation before the project was completed in 1995. The tourist market dictated a design with high reliability and enough power to cover all peak periods.

The field experience of the Canary Island hybrid energy project revealed several key conclusions. First, a rigorous study of the wind conditions, customer load profiles and maintenance costs must be completed before construction begins, as even small errors can have far-reaching technical and financial consequences. Second, the breakeven cost of the project versus the old supply scheme was obtained when diesel fuel costs $\$ 3.67 /$ gallon, thus a dieselonly option is less expensive as diesel fuel costs are below $\$ 3.00 /$ gallon. Third, administrative problems that were encountered point to a need for extensive training of local personnel in maintenance work, and for clear authority to be given from the start of the project to those individuals who will run the equipment and collect energy payments (Carta and Gonzalez, 2001). The need for high reliability and demand coverage increased the costs of the project, as did maintenance costs arising from the remote nature of the site. 


\section{INDIA CASE STUDY}

To further test the economic viability of DG technology in developing countries a case study method has been employed in Gujarat. Based on a detailed fieldwork data collection exercise a model-based analysis of the relative economics of alternative DG configurations versus gridconnected power has been carried out. The data and modelling results from this exercise are presented in the remainder of this section.

\subsection{Geography and Development}

Kachchh is an arid, semi-desert area of Gujarat state which borders Pakistan to the northwest, and Rajasthan to the northeast. Formerly a princely state, Kachchh was established in the fourteenth century by Rajputs, incorporated under British rule in 1815, and made part of Gujarat in 1960. The Rann of Kachchh $\left(23,310 \mathrm{~km}^{2}\right)$, a salt-covered wasteland mainly in the north of the district, was the scene of Indo-Pakistani fighting in 1965. A strong earthquake devastated much of the region in January 2001.

Kachchh is a high-risk environment for water, characterised by arid conditions and vulnerability to seawater intrusion into aquifers. Average yearly rainfall is $300-400 \mathrm{~mm}$, but droughts are frequent and summer temperatures reach $49^{\circ} \mathrm{C}$ (Mehta, 2001). Poor agricultural conditions (only $15 \%$ of the land is arable) and intermittently plentiful grasslands have encouraged widespread animal husbandry (Dyer, 2000). All of Kachchh's 97 rivers are nonperennial and have a high run-off rate. Rainfall is erratic and variable and rain usually falls less than 15 days per year. On average, Kachchh has a declared drought occurring every two to three years (Mehta, 2001) and, as a result, farmers have had to rely on groundwater pumped by electric or diesel pumpsets. The subsidised rates of electricity for agriculture users have led to the rapid depletion of groundwater sources, with aquifers falling tens of metres in the space of a decade in some cases, and many wells having increased salinity levels from sea water incursion (Kumar, 2000).

The Kachchh district is sparsely populated with 1.26 million people counted in the $1991 \mathrm{GoI}$ census, but it has experienced rapid population growth (122\%) since joining the India Union in 1947. This rapid growth has put pressure on natural resources and government services. The scheduled caste and tribal makeup of the district is $11.9 \%$ and $6.95 \%$ respectively and the sex 
ratio is relatively high for Gujarat at 973 females per 1000 males. Kachchh urbanisation rates are $30.7 \%$ and literacy rates are approximately $10 \%$ lower than the Gujarat average of $61.3 \%$ (NCAER, 2002).

Kachchh has nine talukas, or administrative sub-districts, with Bachau and Rapar on the eastern edge of the district. Located adjacent to Rapar, the 'island' of Khadir formed by a raised piece of land surrounded by the salt flats, is actually administered within Bachau taluka, and the administrative centre and closest hospital is located in Bachau town, some $110 \mathrm{~km}$ away. The distance to Bachau and the $8 \mathrm{~km}$ stretch of Rann to the mainland of Kachchh has historically cut off Khadir from the rest of the district and hampered the flow of resources to the 'island'. Bachau taluka encompasses 71 villages with a population of 115,000 , but only 10 villages and 11,000 people are in Khadir. The remoteness and the length and fragility of the local power grid made Khadir a good choice as the site for the hybrid power system modelling case study found in the next sections. Figure 2.1 shows the relative position of the island with respect to India and the rest of Kachchh. The thin lines represent the borders of the villages, and the thicker lines indicate roads.

Figure 2.1: Map of Khadir

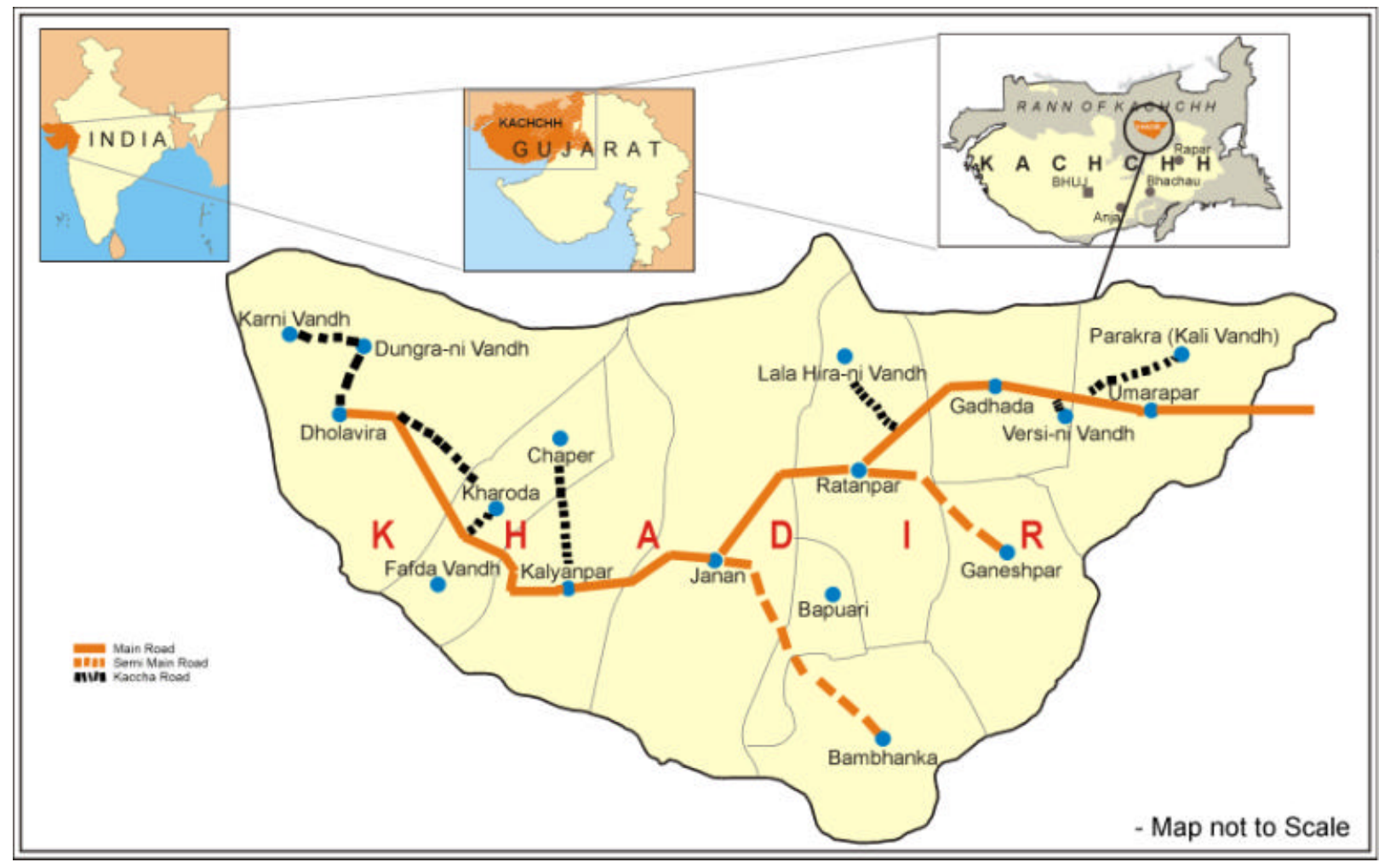

Source: (SAATH, 2002) 
The economic base of the district relies largely on the diverse natural resource-base, offering many primary opportunities for income generation, including dry land and irrigated agriculture, as well as animal husbandry. Skill-based activities and employment in industries and handicrafts are also important (UNDP, 2003). The area has historically been neglected by government programs (Joshi, 2003), but the discovery of a walled city from the Indus Valley civilisations of 4000 B.C. may spur additional visitors and tourist income when it is more fully developed. The Government of Gujarat has constructed a full service tourist hotel near the site on the western edge of the island and plans to open the site for visitors in 2003.

The total population of Khadir is 11,020 according to a 2001 survey conducted by SAATH (2002) for their work related to rehabilitation of the island after the 2001 earthquakes. The population results from the detailed survey are almost twice as large as the $1991 \mathrm{GoI}$ census figures of 6,812, which indicates either rapid population growth or significant undercounting, or perhaps a combination of the two. Table 2.1 contrasts the two sets of figures. The more recent SAATH data are used for the case study development.

Table 2.1: Khadir villages, households and population 2001

\begin{tabular}{|c|c|c|c|c|c|c|}
\hline \multirow[t]{2}{*}{ \# } & \multirow[t]{2}{*}{ Village/ Hamlet } & \multicolumn{2}{|c|}{ SAATH Survey (2001) } & \multicolumn{3}{|c|}{ GoI Census Data (1991) } \\
\hline & & Households & Population & Area in Hectares & Households & Population \\
\hline \multirow[t]{2}{*}{$\mathbf{1}$} & Dholavira & 298 & 1490 & $5,287.43$ & 288 & 1364 \\
\hline & Dungra-ni-Vandh & 55 & 275 & & & \\
\hline 2 & Kharoda & 65 & 325 & $1,993.91$ & 46 & 275 \\
\hline \multirow[t]{3}{*}{3} & Kalyanpar & 206 & 1030 & $1,895.68$ & 191 & 967 \\
\hline & Champer & 43 & 215 & & & \\
\hline & Fafra Vandh & 35 & 175 & & & \\
\hline \multirow[t]{2}{*}{4} & Janan & 276 & 1380 & $4,844.68$ & 144 & 779 \\
\hline & Parkara Dholi Vandh & 30 & 150 & & & \\
\hline 5 & Babhanka & 250 & 1250 & $2,170.39$ & 112 & 622 \\
\hline 6 & Bapuari & 12 & 60 & 587.54 & 0 & 0 \\
\hline \multirow[t]{2}{*}{7} & Ratanpar & 175 & 875 & $5,384.44$ & 122 & 630 \\
\hline & Lalhira Vandh & 65 & 325 & & & \\
\hline \multirow[t]{2}{*}{8} & Gadhada & 106 & 530 & $2,795.03$ & 88 & 398 \\
\hline & Verashi-no-Vandh & 75 & 375 & & & \\
\hline 9 & Umarapar & 320 & 1600 & $3,723.01$ & 201 & 1021 \\
\hline 10 & Ganeshpar & 193 & 965 & $2,723.68$ & 145 & 756 \\
\hline & Totals & 2,204 & 11,020 & $31,405.79$ & 1,337 & 6,812 \\
\hline
\end{tabular}

Source: (SAATH, 2002)

Population size is important for DG planning because low population densities, as in Kachchh, make grid connection options more expensive. The other facet of the population that must be 
considered is caste and group identities. Khadir Island has a large variety of castes and subgroups as identified by the SAATH survey. The caste differences are apparent in the level of income and land ownership and would play an important role in obtaining local political support for a hybrid energy project. The limited duration of fieldwork time in Khadir did not allow for documentation of the caste dynamics of the area, but several tentative conclusions can be drawn from the data, shown in Table 2.2, as well as from conversations with NGO workers familiar with the area (Joshi, 2003).

Table 2.2: Khadir villages, number of households by caste/group 2001

\begin{tabular}{|c|c|c|c|c|c|c|c|c|c|c|c|c|c|}
\hline \# & Village/ Hamlet & Koli & Ahir & Darbar & $\begin{array}{l}\text { Ghad- } \\
\text { havi }\end{array}$ & Muslim & $\begin{array}{c}\text { Maharaj/ } \\
\text { Brahmin }\end{array}$ & Bawaji & Rabari & Bhil & Jarijan & Others & Total \\
\hline \multirow[t]{2}{*}{1} & Dholavira & 182 & 39 & 46 & $\overline{0}$ & 0 & 0 & 5 & 12 & 1 & 54 & 11 & 350 \\
\hline & Dungra-ni-Vandh & 31 & 0 & 0 & 0 & 0 & 0 & 0 & $\underline{0}$ & 0 & 0 & 0 & 31 \\
\hline 2 & Kharoda & 0 & 0 & 67 & 0 & 0 & 0 & 2 & 0 & 0 & 0 & 0 & 69 \\
\hline \multirow[t]{3}{*}{3} & Kalyanpar & 148 & 45 & 0 & 0 & 8 & 0 & 0 & 1 & 0 & 1 & 3 & 206 \\
\hline & Champer & 0 & 6 & 0 & 0 & 0 & 0 & 0 & 0 & 37 & 0 & 0 & 43 \\
\hline & Fafra Vandh & 35 & 0 & 0 & 0 & 0 & 0 & 0 & 0 & 0 & 0 & 0 & 35 \\
\hline 4 & Janan & 14 & 2 & 51 & 17 & 13 & 50 & 0 & 25 & 0 & 29 & 75 & 276 \\
\hline \multirow{2}{*}{$\begin{array}{l}5 \\
6 \\
\end{array}$} & Babhanka & 53 & 0 & 35 & 0 & 0 & 110 & 42 & 0 & 0 & 12 & 2 & 254 \\
\hline & Bapuari & 5 & 5 & 0 & 0 & 0 & 0 & 0 & 0 & 0 & 0 & 0 & 10 \\
\hline \multirow[t]{2}{*}{7} & Ratanpar & 6 & 103 & 0 & 0 & 1 & 0 & 0 & 25 & 6 & 36 & 4 & 181 \\
\hline & Lalhira Vandh & 41 & 0 & 0 & 0 & 1 & 0 & 0 & 0 & 0 & 0 & 0 & 42 \\
\hline \multirow[t]{2}{*}{8} & Gadhada & $\overline{0}$ & 5 & 7 & $\overline{0}$ & 12 & 0 & 11 & 31 & 40 & 0 & 0 & 106 \\
\hline & Verashi-no-Vandh & 48 & 0 & 0 & 0 & 0 & 0 & 0 & 0 & 0 & 0 & 0 & 48 \\
\hline 9 & Umarapar & 37 & 159 & 13 & 0 & 63 & 0 & 0 & 11 & 2 & 8 & 5 & 298 \\
\hline \multirow[t]{2}{*}{10} & Ganeshpar & 0 & 134 & 6 & 0 & 0 & 0 & 0 & 8 & 0 & 39 & 6 & 193 \\
\hline & Total & 600 & 498 & 225 & 17 & 98 & 160 & 60 & 113 & 86 & 179 & 106 & 2142 \\
\hline & Percent of Total & $28.0 \%$ & $23.2 \%$ & $10.5 \%$ & $0.8 \%$ & $4.6 \%$ & $7.5 \%$ & $2.8 \%$ & $5.3 \%$ & $4.0 \%$ & $8.4 \%$ & $4.9 \%$ & \\
\hline
\end{tabular}

Source: (SAATH, 2002)

Caste identity plays an important role in household location. For example, in the first village listed, Dholavira, a small separate hamlet of exclusively Koli caste members is located $1.5 \mathrm{~km}$ away from the main village. The same pattern emerges in Ratanpar and Gadhada, where scores of Koli families live separately from the main villages. The majority of 'high' caste Brahmins reside in Babhanka, a village with zero Muslim families, a group that is overwhelmingly found in Umarapar. Caste dynamics would have an important role in hybrid project site selection and feasibility and local political power structures cannot be ignored. 


\subsection{Electrical Supply Situation and Grid Power Total Costs}

The current level of service from the GEB through the grid is not adequate for local needs and is a deficit-incurring venture for the utility. High levels of theft/illegal connections exist ${ }^{3}$ and the area receives intermittent supplies with high voltage fluctuations. One reason for the poor service is that the village load centres of Khadir are located $25 \mathrm{~km}$ from the $66 \mathrm{kV}$ substation in Balasar in the Rapar Taluka at their closest points.

Khadir is connected to the grid by a $25 \mathrm{~km} 33 \mathrm{kV}$ line, as shown in Figure 2.2. and denoted by the dotted line from the mainland to the island in Figure 2.3. The length of this line leads to high T\&D losses as well as vulnerability of the line in the salt flats (Rann) to cyclones and wind damage. This structural fact combined with the high distribution transformer failure rate in Kachchh, as high as $25 \%$, means that the cost of delivered grid power is higher than for most rural areas of Gujarat, see section 2.5.7 for a detailed calculation.

Figure 2.2: Transmission line across the Rann and GEB substation in Balasar
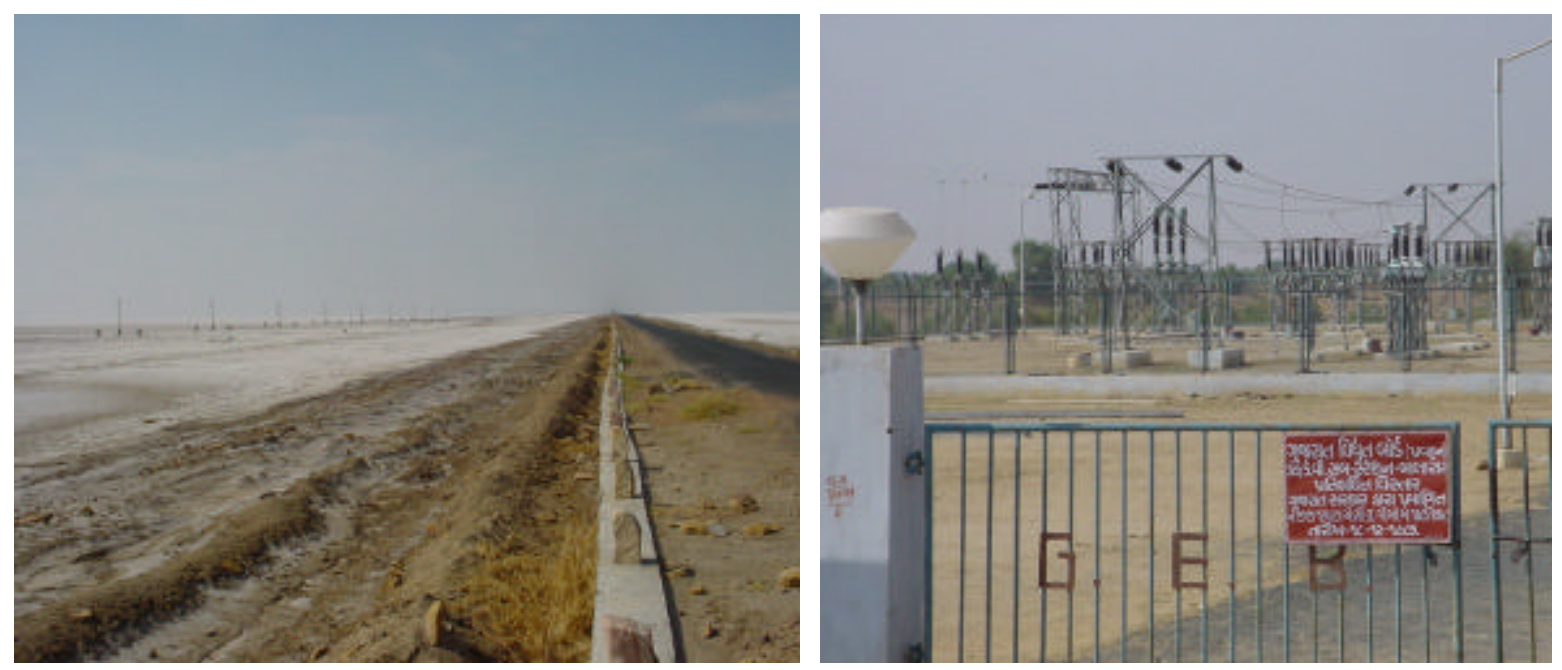

\subsection{Incentives for RE and Hybrid Projects}

IREDA has concentrated on large-scale, grid-connected projects for wind systems, and invests in projects on a commercial basis. However, a new loan program under the Accelerated Rural Electrification Program (AREP) has approved a 4\% interest subsidy scheme on loans taken by SEBs from banks to accelerate rural electrification. The proposal intends to ensure $100 \%$ 
electrification of all villages by the end of the Tenth Plan period, 2012 (TNN, 2003). However, the loans are only currently available to SEBs and leave DG projects to fend for themselves, or get by on the funding available through the MNES.

Figure 2.3: Schematic of the transmission grid in northeastern Kachchh.

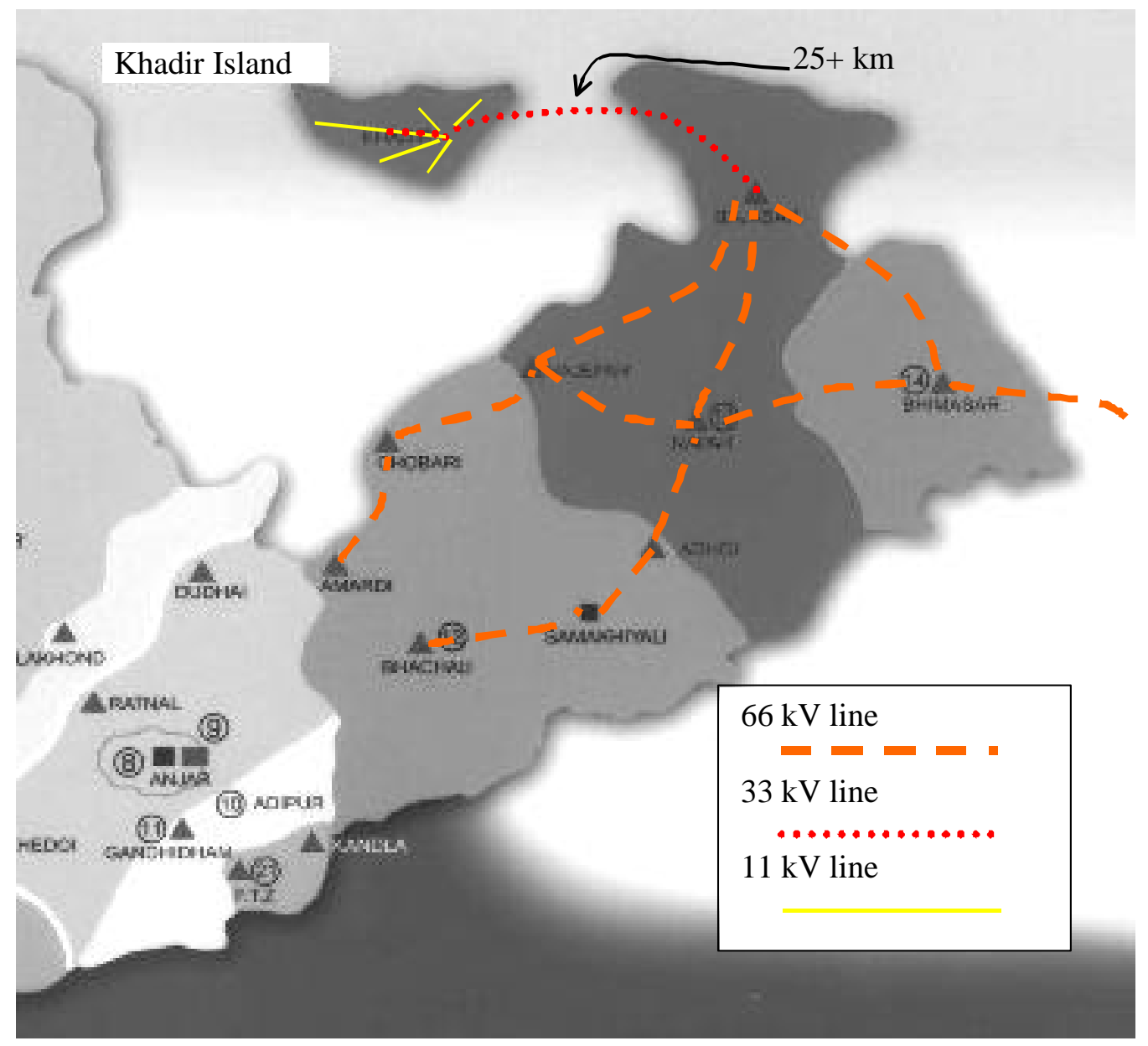

The federal tax code currently allows for a one-year accelerated depreciation of all wind turbine capital investments, which led to a huge boom in wind turbine investment in the earlyto mid-1990s. The effect of the incentive for wind was somewhat offset by the introduction of the Minimum Alternate Tax (MAT) of 12.9\% in the 1996/1997 budget for companies going for 'zero-tax planning'. Companies that had used wind turbine installation as a tax shelter were forced to pay at least $12.9 \%$ in tax on their book profits. Thus, MAT made it less financially beneficial to invest in wind.

\footnotetext{
${ }^{3}$ In Janan alone, the author estimates that $60 \%$ of the connections were illegal. When asked if the GEB inspects the area, a village farmer replied that yes they come to disconnect illegal wires, but that the connections are replaced the next day by the villagers.
} 
The accelerated depreciation may also have had a long-term damaging effect for the wind industry, for two reasons. First, it encouraged companies to make hasty decisions around the time of tax-filings to install wind plants and the tax rule did not reward the actual performance of wind turbines. These hasty decisions often led to bad site selection for turbines and consequently low performance. Second, the rule relies on the ability to absorb the tax benefits, thus restricting wind investment to companies with large balance sheets, such as the textile and cement industries (Kumar, 1999).

The tax benefits for wind also include exemptions in excise duty, exemption from central sales tax, and customs duty, and concessions on the import of materials, components and equipment used in wind electric generators. Individual states have additional tax policies on top of the federal incentives. In Gujarat, the state excise duty is eliminated for $30 \%$ of windpower installed capacity (CECL, 2003).

The buy-back policy from the GEB has been variable in the last ten years for wind turbines, and has had a dampening effect on investment. The current approach (2003) requires the GEB to buy power at a rate of Rs $2.6 / \mathrm{kWh}$ with a built-in escalation of Rs $0.05 / \mathrm{yr}$. Power can also be routed to the wind farm owner's manufacturing units with a low relative wheeling charge of $4 \%$, and power banking is also allowed within a six-month time limit. These intra-firm power transfers are exempt from the electricity duty and help to reduce power costs associated with the high, high tension (HT) tariffs to which industry is subject (Patil, 2003). The extension of buy-back to small DG, grid-connected projects will improve their economics by providing an additional revenue stream when excess power is available.

The MNES has established an incentive program for small wind turbines and hybrid systems, but only for the RE portion of the project, i.e. he MNES will not allow payment for diesel generators. A maximum support of $80 \%$ of the project cost, with a cap of Rs 200,000 is offered for community applications. However, only indigenously manufactured and assembled turbines can be used (MNES, 2002).

Despite the new centre Electricity Bill that recognises DG as an important part of the rural energy solution, little actual policy action has taken place to aid DG and a non-conducive regulatory environment exists for small-scale energy projects. There is no uniform policy or approach of the regulators with regard to [DG] schemes.' (MoP, 2002):58) Investment is 
almost non-existent because of regulatory uncertainty and few production incentives for energy entrepreneurs. Instead, the state and local governments have given more resources to the actors least likely to deliver better services, the SEBs. The economics of many DG projects/enterprises is heavily dependent on government policies towards interest rates, accelerated depreciation, tax credits and so on. Uncertainty with regard to them affects the economics of DG projects and increases hesitation on the part of financial institutions to finance DG schemes (MoP, 2002). For the analysis in this paper, no assumptions were made regarding RE incentives, thus any provided would increase the economic viability of a project.

\subsection{Comparative Economic Analysis}

The choice between competing technologies for rural energy services can be informed by a financial comparison between the different options. The difficulty in properly costing the environmental and social benefits of different types of power projects limits the scope of this paper to quantitative results of financial indicators. However, non-monetary advantages of DG systems are described in Section 3.1 using qualitative and quantitative measures to estimate final benefits.

Taking into account the local conditions in Kachchh and the findings from the previous section requires a flexible decision-making tool. The analysis in this paper uses the HOMER model to compare a range of hybrid and centralised options. HOMER identifies the least-cost system for supplying electricity to remote loads by performing hourly simulations of thousands of potential power systems and rank ordering them by life-cycle costs. It also performs sensitivity analyses to evaluate the impact of a change in any of the input parameters and provides both annual and hourly outputs (NREL, 2003). Hybrid system design is made difficult by the intermittency of renewable resources, the need to match electrical supply and demand, and the large number of potential component size combinations. The hourly simulation performed by HOMER can handle the constantly changing conditions.

The model allows for rapid calculation of thousands of different alternative systems' net present value (NPV) and the derivative of NPV, cost of energy (COE). NPV is the best indicator of a project's economic value, as it properly accounts for the opportunity costs of capital (Brealey and Myers, 2000). By comparing the NPV and the COE, a ranked order of projects can be obtained and alternatives can be compared on a like basis, the return on capital, 
which is the main limiting factor for electricity projects in India. Note that all costs in this paper are presented in real 2003 U.S. dollars or rupees using Rs 48:\$1 exchange rate. The specifics of the model are described in the Appendix to this document and the next section details the input assumptions for the model.

Three types of generation components, wind turbines, diesel and PV, as well as the inclusion of battery power storage are mixed and matched to compare systems and find the optimal result for one village in Khadir. While it is possible to expand the project to include many villages simultaneously, the first project is likely to be for one village, and then expanded in phases, similar to the experience on Sagar Island (Natarajan, 2002).

\subsection{Input Data}

\subsubsection{Generation Equipment and Fuel Cost Assumptions}

Diesel genset expenses are displayed in Table 2.3 and reflect the decreasing cost per $\mathrm{kW}$ economies of scale of larger units. The lower replacement costs account for the fact that a new genset can take advantage of the old one's housing and electrical hook-ups.

Table 2.3: Diesel genset cost assumptions

\begin{tabular}{|r|rr|r|r|}
\hline $\begin{array}{c}\text { Rated Capacity } \\
(\mathrm{kW})\end{array}$ & $\begin{array}{c}\text { Capital Cost } \\
(\$)\end{array}$ & \$/kW & $\begin{array}{c}\text { Replacement } \\
\text { Cost }(\$)\end{array}$ & $\begin{array}{c}\text { O\&M Cost } \\
(\$ / \mathrm{hr})\end{array}$ \\
\hline \hline 15 & 4000 & 267 & 3000 & 0.3 \\
25 & 6000 & 240 & 6000 & 0.5 \\
35 & 8000 & 229 & 7000 & 0.7 \\
50 & 11000 & 220 & 10000 & 1.0 \\
100 & 20000 & 200 & 19000 & 2.0 \\
\hline
\end{tabular}

Diesel fuel prices can vary widely in rural India, depending heavily on transport costs. In Gujarat, the urban (Ahmedabad) price of diesel as observed in January 2003 was Rs 19/litre. The price in rural Kachchh (Rapar) was Rs 21/litre and in Khadir it was Rs 22/litre because of transport surcharges. The assumption for diesel costs in the model is a baseline of $\$ 0.45 /$ litre or Rs 21.6 with a range of $\$ 0.40$ to $\$ 0.50$ tested for sensitivity.

Two types of wind turbines are modelled for use in Khadir, one large and the other smaller, to test for different sizes. First, the $50 \mathrm{~kW}$ Atlantic Orient Company 15/50 was estimated to cost 
$\$ 75,000$ for capital costs plus 5\% for installation and 10\% for O\&M for 10 years (Barley, Meares, and Flowers, 1998). The second turbine evaluated was the Bergey Excel-S, $10 \mathrm{~kW}$ model, which was estimated to cost $\$ 24,000$ per unit plus $15 \%$ for installation and 10-year maintenance. The PV panels that are tested are assumed to cost $\$ 6000 / \mathrm{kW}$ for capital expense. Installation costs are included in the project capital of $\$ 40,000$, based on a similar project (Bakos and Soursos, 2002; Schmid and Hoffmann, 2003).

For the biogas-fuelled generation assets, a capital cost of $1000 \$ / \mathrm{kW}$ was used with an O\&M expense of $0.1 \$ / \mathrm{kWh}$ for all sizes of engines $(5-20 \mathrm{~kW})$. These costs include the digester, piping, filters, engine and generator plus the cost of building and were based on case study work done by Ravindranath and Hall (1995).

\subsubsection{Auxiliary Equipment Cost Assumptions}

The energy storage, control and electrical equipment needed for a hybrid system can be extensive, depending on the system's configuration. To allow for systems with power storage to be modelled, a set of cost assumptions was developed for auxiliary components, including inverters, batteries, synchronising electronics and generator controls based on similar past projects (Morris, 1998). Inverters cost $\$ 750 / \mathrm{kW}$ of capacity and $\$ 8 / \mathrm{kW}$-yr for O\&M. Batteries (Trojan T-16 model) cost $\$ 100 / \mathrm{kW}$ of capacity and $\$ 5 / \mathrm{yr}$ for O\&M.

\subsubsection{Load Profiles}

The total load or power demand on the hybrid system has been split into three parts for modelling purposes:

i. Primary Load 1: domestic and agriculture irrigation pumping;

ii. Primary Load 2: light industrial (concrete parts for house construction); and

iii. Dump load (water pumping for domestic use and refrigeration).

The primary loads are added together to obtain the aggregate demand and the dump load is treated as deferrable.

The lack of any demand data for Khadir villages necessitated the estimation of load based on previous studies in Gujarat and other parts of India (Ravindranath and Hall, 1995). Table 2.4 
shows the different villages in Khadir and their calculated demand per day. Villages numbered 1, 4 and 9 all fit the profile for a medium-sized hybrid project. Project experience in West Bengal shows that demand starts at low levels and grows steadily as customers increase income and buy appliances to use the energy (Natarajan, 2002). To reflect this, a 50\% reduction is made from the assumed long-term per capita consumption figures $(0.46 \mathrm{kWh} /$ day $)$. As a result, $385 \mathrm{kWh} /$ day is used as a starting demand total for primary load 1 (PL 1) in the model for one village, and then tested for $150 \%$ and $200 \%$ of starting levels in the simulation.

Table 2.4: Khadir village electricity demand assumptions

\begin{tabular}{|r|l|r||r|r|}
\hline$\#$ & Village/ Hamlet & $\begin{array}{c}\text { Population } \\
\mathbf{2 0 0 1}\end{array}$ & $\begin{array}{c}\text { Total Demand } \\
\text { (kWh/day) }\end{array}$ & $\begin{array}{c}\text { Assumed Starting } \\
\text { Demand (50\%) }\end{array}$ \\
\hline \hline $\mathbf{1}$ & Dholavira & 1490 & 694 & 347 \\
& Dungra-ni-Vandh & 275 & 128 & 64 \\
\hline $\mathbf{2}$ & Kharoda & 325 & 151 & 76 \\
\hline $\mathbf{3}$ & Kalyanpar & 1030 & 480 & 240 \\
& Champer & 215 & 100 & 50 \\
& Fafra Vandh & 175 & 82 & 41 \\
\hline $\mathbf{4}$ & Janan & $\mathbf{1 3 8 0}$ & $\mathbf{6 4 3}$ & $\mathbf{3 2 1}$ \\
& Parkara Dholi Vandh & $\mathbf{1 5 0}$ & $\mathbf{7 0}$ & $\mathbf{3 5}$ \\
\hline $\mathbf{5}$ & Babhanka & 1250 & 582 & 291 \\
\hline $\mathbf{6}$ & Bapuari & 60 & 28 & 14 \\
\hline $\mathbf{7}$ & Ratanpar & 875 & 408 & 204 \\
& Lalhira Vandh & 325 & 151 & 76 \\
\hline $\mathbf{8}$ & Gadhada & 530 & 247 & 123 \\
& Verashi-no-Vandh & 375 & 175 & 87 \\
\hline $\mathbf{9}$ & Umarapar & 1600 & 745 & 373 \\
\hline $\mathbf{1 0}$ & Ganeshpar & 965 & 449 & 225 \\
\hline \multicolumn{1}{|c|}{ Totals } & $\mathbf{1 1 , 0 2 0}$ & $\mathbf{5 , 1 3 3}$ & $\mathbf{2 , 5 6 6}$ \\
\hline
\end{tabular}

Note- per capita estimated demand $=.46 / \mathrm{kWh}$ per day

The other important load characteristic that must be taken into account is how the load is distributed throughout the day. Based on other rural energy studies (Barley, Meares, and Flowers, 1998), an evening weighted curve was constructed for the Khadir village case study, and is shown in Figure 2.4. 
Figure 2.4: Load profile for PL 1 (large village in Khadir)

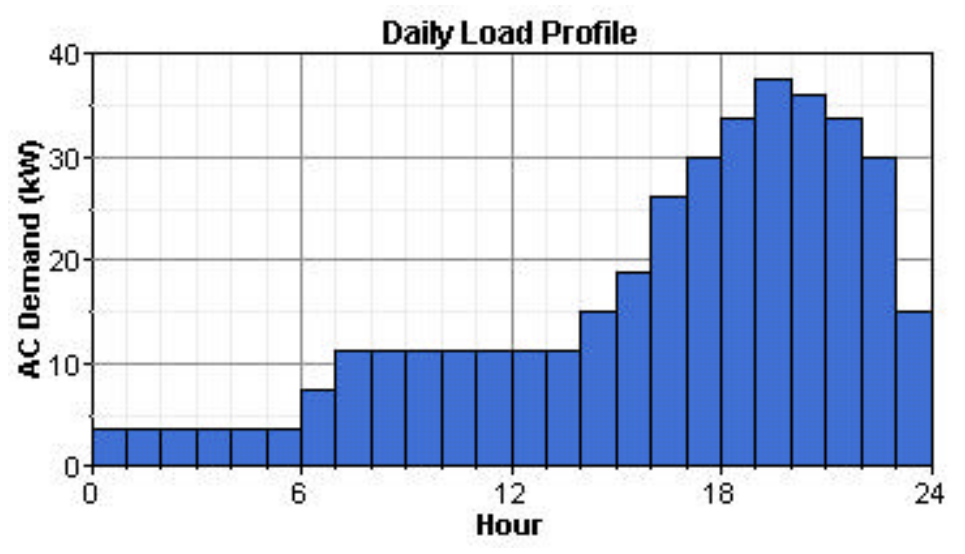

The high use during the evening hours reflects the high demand for lighting and power for radio and television and the lower relative demand for industrial uses in rural areas. Figure 2.5 shows portions of the Janan village with satellite TV aerial in the background and the range of electrical equipment used in a wealthy household.

Figure 2.5: Khadir village and electronic equipment, January 2003
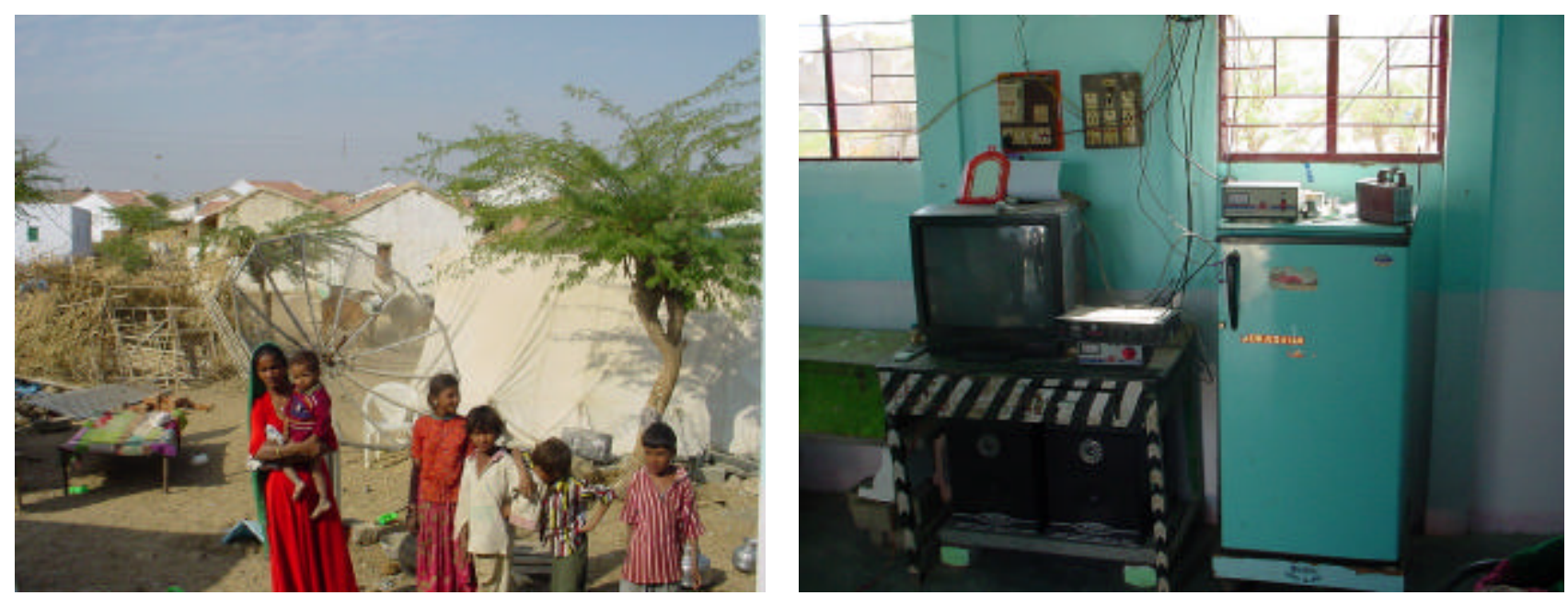

PL 2 is based on a Gujarat NGO- (named SAATH) sponsored small concrete parts factory in Khadir to manufacture prefabricated housing pieces from concrete. To ensure a steady power supply, SAATH was not able to use the grid, and was forced to purchase a $15 \mathrm{~kW}$ diesel genset to supply power to the factory; the load is detailed in Table 2.5 and the factory and genset are pictured in Figure 2.6. 
The factory operates seven days a week from 7.00 AM to 11.00 PM, with two shifts of workers. The equipment requires a reliable three-phase supply during all operating hours and the demand is near the full capacity of the genset. The engineer in charge commented that the addition of more than a light bulb would trip the system and he estimates that the load factor during operating hours was near 95\%. Figure 2.7 displays the assumed load profile of the factory and was used in the HOMER model as a second primary load.

Figure 2.6: Concrete parts factory and $15 \mathrm{~kW}$ diesel genset, Khadir Island, Gujarat
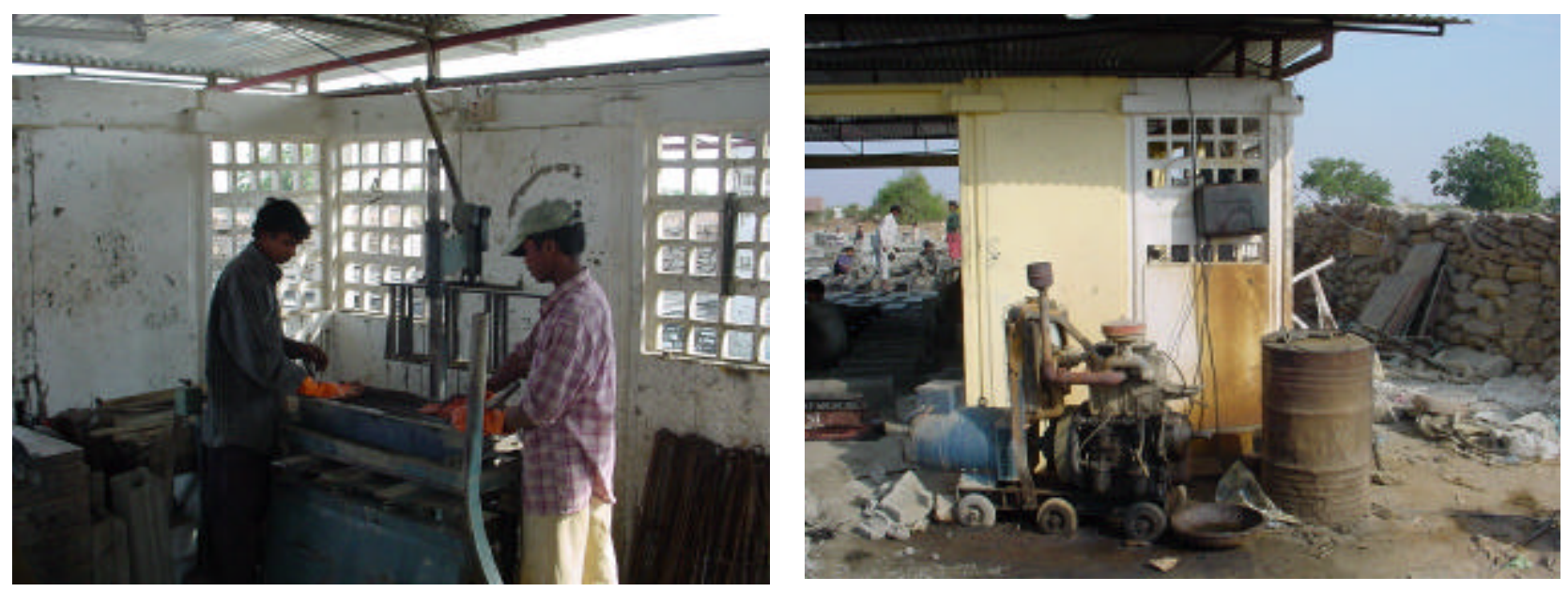

Table 2.5: Load devices for concrete factory

\begin{tabular}{|l|r|}
\hline \multicolumn{1}{|c|}{ Equipment in Use } & Number \\
\hline \hline Welding Set & 2 \\
Grinder Set & 1 \\
Concrete Mixing Machine & 1 \\
Table Vibrator & 2 \\
Vibro-Press & 1 \\
Vibrator & 1 \\
Drilling Machine & 1 \\
60 Watt Incandecent light & 15 \\
40 W tubelight & 4 \\
\hline
\end{tabular}

Hybrid systems also need a deferrable dump load to help maintain system stability during periods of high wind turbine power production or to prevent the diesel from running at lower than $40 \%$ rated output, which can damage the engine (Barley, Meares, and Flowers, 1998). In Khadir, the deferrable load is rated at $15 \mathrm{~kW}$, and would most likely be a water pump for domestic/livestock water demand or for a refrigeration unit to store dairy products and thus increase sales to local food co-operatives. 
Figure 2.7: Load profile for PL2 (small concrete parts factory)

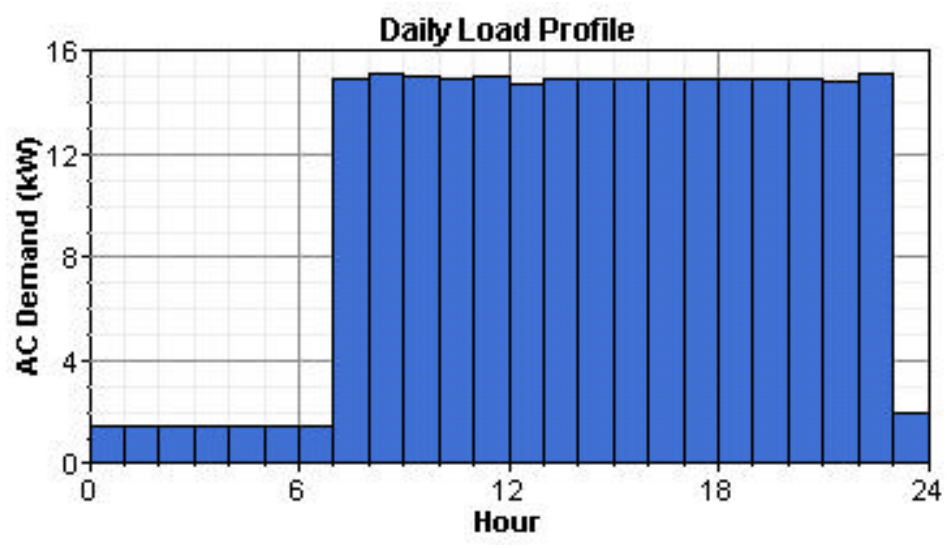

\subsubsection{Wind Resources}

Wind resources in Kachchh are adequate for economic deployment of wind turbines, however site-specific data for the case study villages were not available. To overcome the lack of data, an estimate based on the wind resources of nearby testing stations, each within $70 \mathrm{~km}$ of Khadir, was used (CECL, 2003), as shown in Table 2.6.

Table 2.6: Wind resource assumptions for Khadir

\begin{tabular}{|c|c|c|c|c|c|c|}
\hline \multirow{2}{*}{ Station } & \multirow{2}{*}{ District } & \multirow{2}{*}{$\begin{array}{c}\text { Elevation } \\
\text { m.a.s.l. }\end{array}$} & \multicolumn{2}{|c|}{$\begin{array}{l}\text { Mean Annual Wind } \\
(\mathrm{m} / \mathrm{s})\end{array}$} & \multicolumn{2}{|c|}{$\begin{array}{l}\text { Mean Annual Wind } \\
\left(\mathrm{W} / \mathrm{m}^{2}\right)\end{array}$} \\
\hline & & & At Mast & $\begin{array}{c}\text { At } \\
30 \mathrm{~m}\end{array}$ & At Mast & $\begin{array}{c}\mathrm{At} \\
50 \mathrm{~m}\end{array}$ \\
\hline Adesar & Kutch & 23 & 5.31 & 5.58 & $\overline{93.4}$ & 307 \\
\hline Kukma & Kutch & 205 & 4.86 & 5.67 & 149.6 & 239 \\
\hline Surajbari & Kutch & 9 & 5.39 & 5.72 & 184.2 & 243 \\
\hline Khadir (assumed) & Kutch & 150 & 4.75 & 5.50 & - & 220 \\
\hline
\end{tabular}

Note - mast height equals $20 \mathrm{~m}$

A conservative baseline annual average wind speed of $4.75 \mathrm{~m} / \mathrm{s}$ at a $20 \mathrm{~m}$ mast height was assumed for the Khadir study site and tested for sensitivity above and below this value; the assumed $30 \mathrm{~m}$ value of $5.5 \mathrm{~m} / \mathrm{s}$ was used as a base-case wind speed value. Khadir wind speeds exhibit strong seasonal changes, with the windiest days occurring from May to August. A Weibull factor of 2.1 and a diurnal pattern strength factor of 0.3 were used to develop an hourly profile of the wind speeds for a hypothetical year. Figure 2.8 shows the probability distribution function of the baseline wind resources assumed for Khadir with the best-fit line smoothing function overlaid. 
Figure 2.8: Probability distribution of assumed wind resources in Khadir

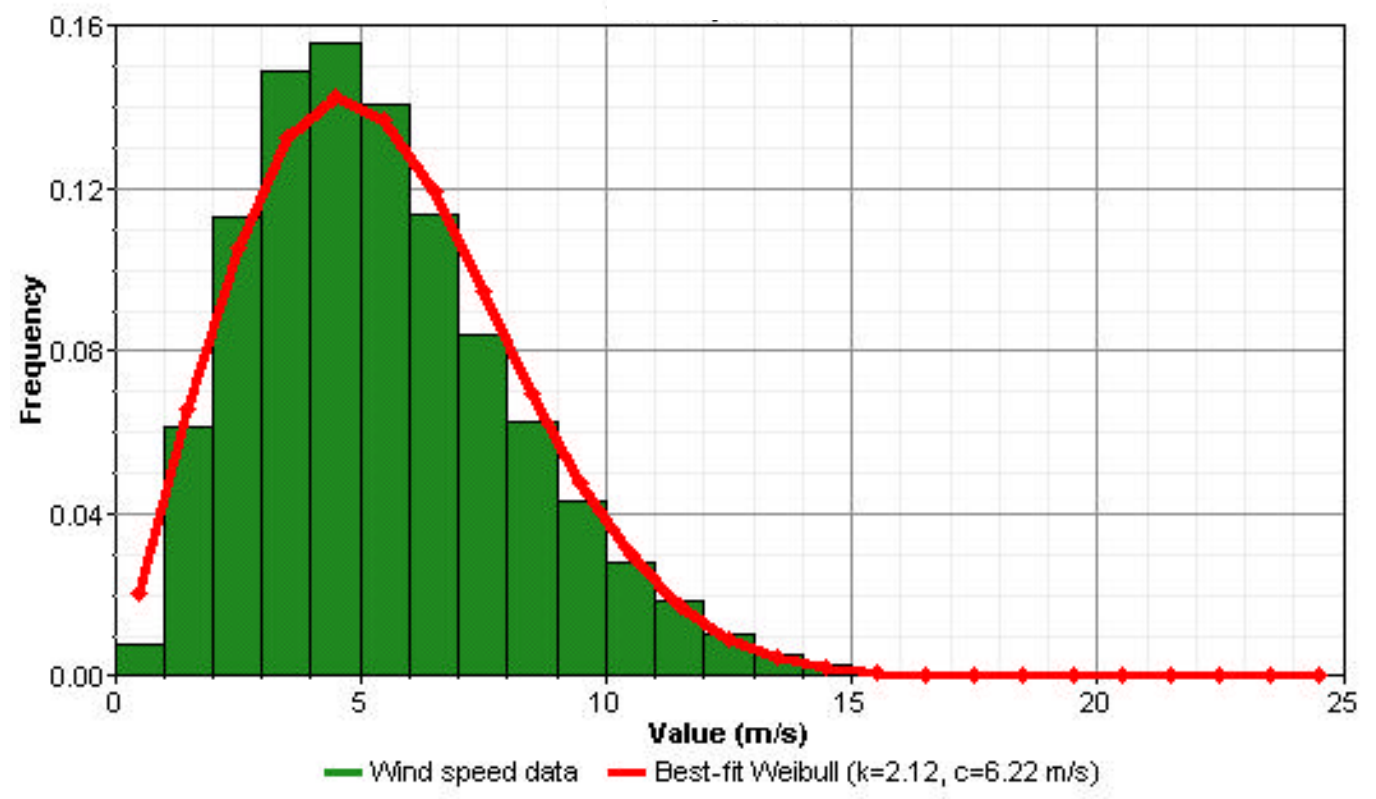

Note: Mean Annual Average $=5.5 \mathrm{~m} / \mathrm{s}$

\subsubsection{Solar Resources}

The solar isolation in Khadir is suitable for solar power and is estimated conservatively at 2100 $\mathrm{kWh} / \mathrm{m}^{2} / \mathrm{yr}$ or an average of $5.75 \mathrm{kWh} / \mathrm{m}^{2}$ per day (Beerbaum and Weinrebe, 2000). The clearness index for Karachi, which is approximately $300 \mathrm{~km}$ northwest of Khadir, was used to determine the total energy available (Duffie and Beckmann, 1991). Figure 2.9 shows the baseline sensitivity of $5 \mathrm{kWh} / \mathrm{m}^{2}$ for solar resources assumed in Khadir and the fluctuation of the clearness index during the year.

Figure 2.9: Assumed solar resources in Khadir

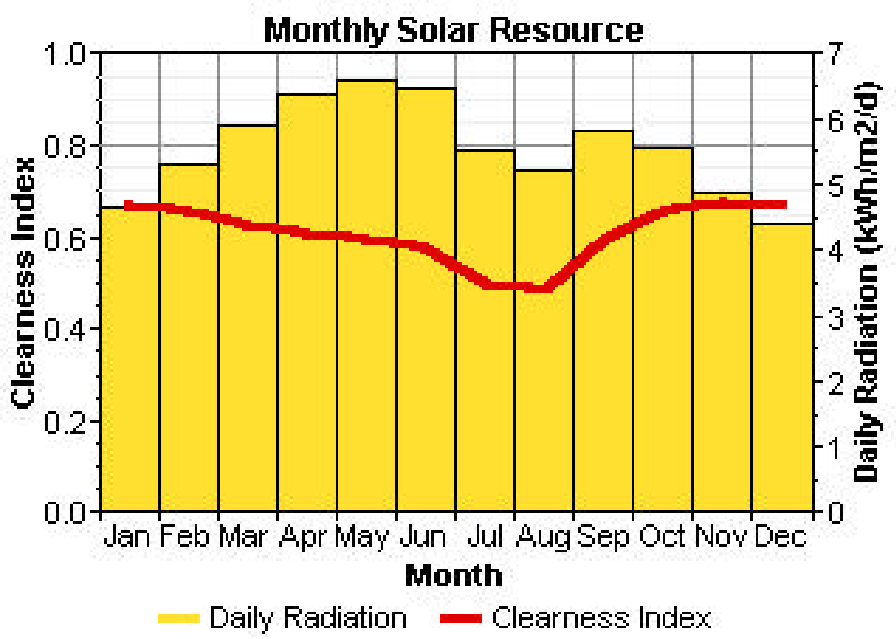




\subsubsection{Biomass Resources}

For completeness, biogas-fuelled electricity generation technologies were considered for Gujarat. The total resources in Khadir are not adequate to support a biogas plant, however, in most areas of rural India biogas is a viable option. The biomass resource base was assumed to be 50 tonnes/day of dung, woody and leafy material and was modelled as costless in the base case and tested for sensitivity at $5 \$$ tonne. The biogas produced by the digester at a ratio of $0.7 \mathrm{~kg}$ of gas $/ \mathrm{kg}$ of biomass is assumed to have a $7 \mathrm{MJ} / \mathrm{m}^{3}$ high heating value and consists of nitrogen, hydrogen and carbon monoxide gases (Richards et al., 2001).

\subsubsection{Load Management Assumptions}

The management of the DG system load is crucial to its economics and operational stability. The baseline assumptions for the modelled system use an unserved load cap of $20 \%$, which means that at peak times and when the availability of windpower is low, the system cuts off supply to no more than $20 \%$ of demand. This allows the system to be undersized, and thus save capital expense. Unserved load requires careful dispatch planning to make sure the commercial users who would face large productivity losses without power are not affected. Instead, luxury load consumers could be offered reduced tariffs in exchange for an interruptible supply. When the supply situation is reversed, the DG system can use any excess power available during periods of high winds and low demand to power deferrable loads - such as ice makers or water pumps for domestic or livestock use. In this way, any excess power produced can be sold to maximise returns. See section 2.6.3 for the operational model results of this approach.

\subsubsection{Grid Capital and Power Cost Assumptions}

The use of large centralised generation facilities typically has a lower long-run average cost of energy than DG systems at 'plant gate', or busbar. However, once T\& D costs are factored in this may not be the case. IPP power generation costs in Gujarat are approximately Rs 3/kWh (PC, 2002), depending on the fluctuation in the price of natural gas, which varies between \$34/MMBTU delivered in Gujarat (Tongia and Banerjee, 1998). The GEB estimates the average cost of energy (COE) at Rs 3.65/kWh (PC, 2002), but the average hides the true costs of delivering power to remote rural areas. To better quantify the cost of delivering power over 
long distances, a useful model was developed by the Antares Group Ltd. in 1997 for India and adjusted below for Gujarat conditions in 2003 (ignoring local distribution costs).

Cost of Delivered Power $=($ Busbar COE $)+[(\mathrm{BLT}+\mathrm{TL}+\mathrm{TH}) *$ Busbar COE $]$

Where:

BLT $=$ Base line transmission costs, cost of capital investment and O\&M for lines

$\mathrm{TL}=$ Transmission Line Losses

$\mathrm{TH}=$ Theft losses

For a traditional power grid, transmission systems require approximately the same capital investment as the generation assets. In Gujarat, transmission accounted for $68 \%$ of expenditure in 2000-01 (GERC, 2000). To account for this investment in T\&D, a BLT of 0.5 is used. To account for the technical losses, a $0.25 \mathrm{COE}$ inflator is used to reflect the costs associated with long distance power transfer. ${ }^{4}$ Finally, a COE inflator of 0.5 was estimated for theft in Kachchh based on the distribution reports from the GEB and GERC (2002). Substituting in Rs 3.65 for the COE busbar and the above estimates, the equation yields,

Cost of Delivered Power $=($ Rs 3.65)*(2.25) $=$ Rs $8.21 / \mathrm{kWh}$

However, the above model does not take into account the high failure rate of distribution transformers in the case study area (Kachchh), which will add to the delivered cost. Thus, the total cost of delivered power for a rural Kachchh area is conservatively estimated to be above Rs 9/kWh. Other field experience in India (Barnes, 1988) indicates that the long-run marginal cost of power delivered to a village is three times the cost of generation, which supports the above result as a reasonable estimate. In the model, the total average cost of grid power was tested from Rs $3 / \mathrm{kWh}$ to $\mathrm{Rs} 8 / \mathrm{kWh}$ to determine the breakeven distance of grid-connected supply versus hybrids. Compared with the initial operational results of the Sagar Island hybrid project, which had COE delivered of Rs $7 / \mathrm{kWh}$; the hybrid project model may be economically feasible and thus deserves more exploration.

The estimated T\&D capital costs for the model inputs were based on information from Rakesh Shah, the Deputy Director of GERC (2003) and cross-checked against inflation-adjusted 
figures from Gujarat (Malaviya and Ranade, 1997). Estimates for HT lines, LT lines and transformers were used to compile an aggregate average cost of $\mathrm{T} \& \mathrm{D}$ per $\mathrm{km}$ in Khadir, as shown in Table 2.7.

Table 2.7: Costs estimate for T\&D system in Kachchh

\begin{tabular}{|l|r|}
\hline \multicolumn{1}{|c|}{ Component } & \multicolumn{1}{c|}{$\begin{array}{c}\text { Price Range for } \\
\text { Rural Areas (Rs '000) }\end{array}$} \\
\hline \hline Transformers & $40-200$ \\
LT lines/km & $80-115$ \\
HT lines/km & $110-210$ \\
\hline Average/km & $\mathbf{3 0 0 - 3 5 0}$ \\
\hline
\end{tabular}

Source: (Shah, 2003)

The average cost per $\mathrm{km}$ is therefore approximately $\$ 6000$ and were tested for sensitivity from $\$ 6,000-10,000$ to account for the difficulty and expense of building transmission lines on the Rann.

\subsubsection{Financial and Operational Assumptions}

IREDA currently loans at a slightly subsidised rate for windpower projects at a rate of $14.5 \%$ (IREDA, 2003) and the average rate of inflation in India has been 5\% per year for the past four years (RBI, 2003). Subtracting inflation from the nominal interest rate yields the real interest rate; for the case study, a value of $10 \%$ was used, which conservatively estimates the real costs of capital for a firm that would invest in a hybrid project. A buy-back price of Rs $3 / \mathrm{kWh}$ for any excess power from the hybrid system was used in the model based on Gujarat policy with continued escalation factored in. Fixed capital costs of $\$ 50,000$ and fixed O\&M of $\$ 2000 / y r$ were used to estimate the costs of auxiliary control systems based on project experience in the Philippines and in West Bengal for wind-diesel hybrids (Morris, 1998; Imhoff, 2003).

\footnotetext{
${ }^{4}$ Antares Group used 0.5 for lines over $360 \mathrm{~km}, 0.25$ for lines 160 to $360 \mathrm{~km}$ and 0 for shorter than $160 \mathrm{~km}$ lines
} 


\subsection{Results}

The level of demand in Khadir is larger than the amount that can be accommodated by small PV systems but smaller than the amount needed to capture significant economies of scale to be served by the grid, meaning the load factor does not support the grid investment. The small manufacturing facility and demand from the village require reliable and high quality threephase power. In this situation three energy options are available to Khadir. First, it can continue with low quality, but highly subsidised grid power; second, install a diesel genset for all uninterruptible demands and thus pay a high marginal cost for the power; or thirdly, install a hybrid system that allows for reliability while reducing the amount of diesel fuel that needs to be transported to the area. This section examines he economic and operational results from the optimisation modelling of a hybrid system in Khadir using the HOMER model.

\subsubsection{Hybrid System Choice}

Applying the baseline assumptions for resources and market observed fuel prices, the use of one $50 \mathrm{~kW}$ wind turbine and one $25 \mathrm{~kW}$ diesel genset with no battery storage or inverters is the optimal system for Khadir with average wind speeds of $5.5 \mathrm{~m} / \mathrm{s}$ and $\$ 0.45 / \mathrm{L}$ for diesel fuel.

Table 2.8 shows the cost comparisons of each category of hybrid system, as well as a dieselonly configuration (ranked 5). Biogas hybrid systems do not compare well with the other options, even with adequate local resources, and are ranked sixth, seventh and eighth accordingly. However, at low load levels, i.e. below $100 \mathrm{kWh} /$ day, biogas performs well compared to diesel units, but the high capital and O\&M costs undercut its effectiveness as loads increase. If O\&M costs were decreased by $40 \%$, to $\$ 0.06 / \mathrm{kWh}$, then biomass becomes the least cost option for most demand levels.

The wind-diesel combination has a net present cost (NPC) of $\$ 366,536$ compared to the dieselonly option of $\$ 435,140$, a $15.7 \%$ decrease in price. The cost of energy is similarly reduced, and the top ranked system produces electricity for Rs $10.66 / \mathrm{kWh}$, which may compete with grid power depending on T\&D loss assumptions. For $6.0 \mathrm{~m} / \mathrm{s}$ wind speeds the costs of energy (COE) falls to $\$ 0.189 / \mathrm{kWh}$ or Rs $8.88 / \mathrm{kWh}$ 
Table 2.8: Categorised ranking of hybrid systems

\begin{tabular}{|c|c|c|c|c|c|c|c|c|c|c|c|}
\hline & \multicolumn{5}{|c|}{ Generation Technology } & \multicolumn{4}{|c|}{ Financial Results } & \multicolumn{2}{|c|}{ System Balance } \\
\hline Rank & $\begin{array}{l}\mathrm{PV} \\
(\mathrm{kW})\end{array}$ & $\begin{array}{l}\text { WTG } \\
(\mathbf{k W})\end{array}$ & $\begin{array}{l}\text { BIO-G } \\
(\mathrm{kW})\end{array}$ & $\begin{array}{c}\text { Diesel } \\
(\mathbf{k W})\end{array}$ & $\begin{array}{l}\text { Battery } \\
\text { \& Inv. }\end{array}$ & $\begin{array}{l}\text { NPC } \\
(\$)\end{array}$ & $\begin{array}{c}\text { Total } \\
\text { Capital (\$) }\end{array}$ & $\begin{array}{c}\mathrm{COE} \\
(\$ / \mathrm{kWh})\end{array}$ & $\begin{array}{c}\mathrm{COE} \\
(\mathrm{Rs} / \mathrm{kWh})\end{array}$ & $\begin{array}{c}\text { Renewable } \\
\text { Fraction }\end{array}$ & $\begin{array}{c}\text { Fuel Usage } \\
\text { (L/year) }\end{array}$ \\
\hline 1 & & 50 & & 25 & $\mathrm{No}$ & 366,536 & 121,000 & 0.222 & 10.66 & 0.42 & 46,333 \\
\hline 2 & & 50 & & 25 & Yes & 367,963 & 122,659 & 0.222 & 10.66 & 0.42 & 46,119 \\
\hline 3 & 5 & 50 & & 25 & $\mathrm{No}$ & 385,309 & 147,459 & 0.231 & 11.09 & 0.45 & 45,300 \\
\hline 4 & 5 & 50 & & 25 & Yes & 385,543 & 147,559 & 0.231 & 11.09 & 0.45 & 45,238 \\
\hline 5 & & & & 35 & $\mathrm{No}$ & 435,140 & 48,000 & 0.255 & 12.24 & 0.00 & 77,673 \\
\hline 6 & 5 & 100 & 20 & & Yes & 484,650 & 236,900 & 0.299 & 14.35 & 0.70 & 30,630 \\
\hline 7 & & 100 & 30 & & Yes & 569,208 & 218,859 & 0.318 & 15.26 & 0.62 & 43,039 \\
\hline 8 & & & 40 & & $\mathrm{No}$ & 757,575 & 76,000 & 0.417 & 20.02 & 0.00 & 84,051 \\
\hline
\end{tabular}

Note - all systems use a 'load following' dispatch strategy and \$1:Rs 47

The other advantage of a hybrid system is the fuel savings, reflected in the last column of Table 2.8 , where fuel useage is in the range of $45,0001 / \mathrm{yr}$, or a savings of more than $40 \%$ compared to diesel only systems. These savings reflect the renewable fraction that displaces the diesel in each case. The power produced by the wind and the genset in the first ranked system over the course of the year is displayed in Figure 2.10; note that the wind generator is operating at $20.6 \%$ capacity utilisation factor.

Figure 2.10: Power generation by source with $5.5 \mathrm{~m} / \mathrm{s}$ wind regime

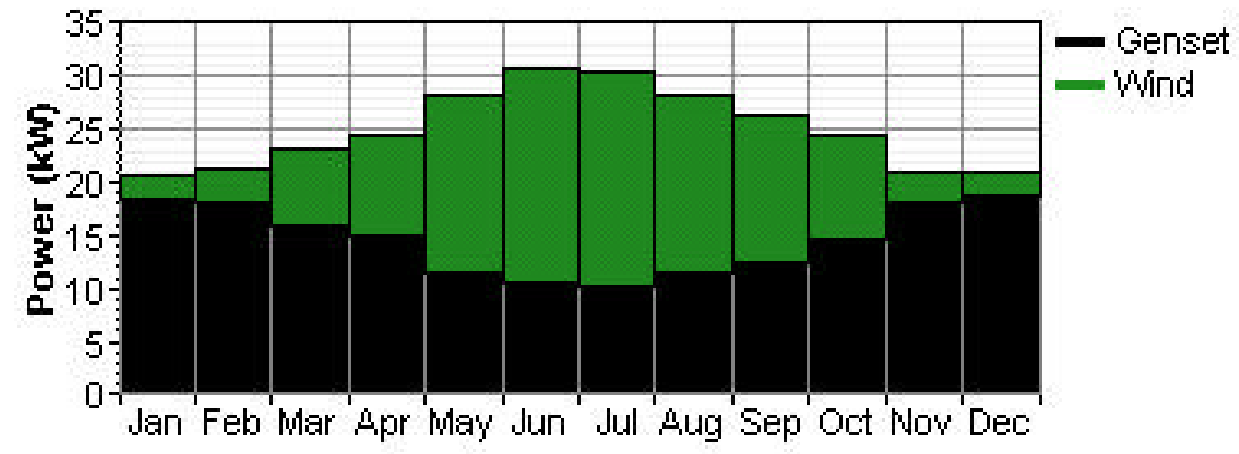

The most important variable in determining the viability of a hybrid system is the wind speed. In Figure 2.11, the sensitivity results are shown for a wind speed range of $4.0 \mathrm{~m} / \mathrm{s}$ to $5.5 \mathrm{~m} / \mathrm{s}$ against changes in primary load levels. Focusing on the x-axis, the lower wind speeds, not surprisingly, show the only-diesel option as the most economical, but that dominance only lasts to $4.75 \mathrm{~m} / \mathrm{s}$ wind speeds, where solar-wind-diesel is the optimal system. As wind speeds approach $5.0 \mathrm{~m} / \mathrm{s}$ the wind-diesel option with battery storage is the best choice, and finally above $5.5 \mathrm{~m} / \mathrm{s}$ wind-diesel is the best option. Now concentrating on the $\mathrm{y}$-axis, at low levels of 
demand all the systems should be considered; however, as demand grows, a likely result in rural India, the dominant system is the wind-diesel without battery storage, which is represented by the majority of the space in Figure 2.11.

Figure 2.11: Optimal system types, primary load 1 vs. wind speed

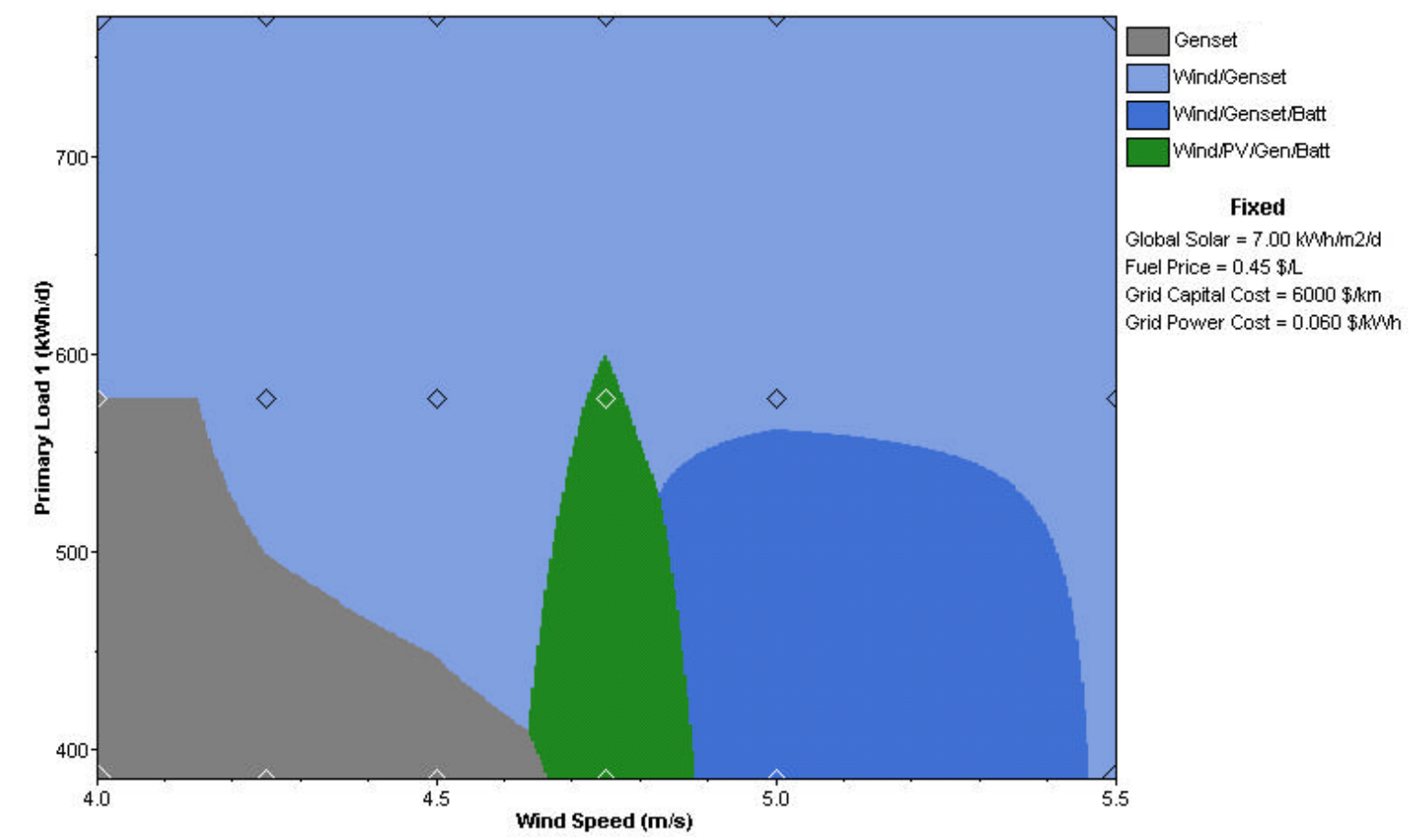

To examine the change in the optimal system type versus the load size further, the two different loads are plotted on the same graph, as shown in Figure 2.12. The results indicate that at more modest wind speeds, $5.0 \mathrm{~m} / \mathrm{s}$ average, the optimal system choice is highly dependent on the load profile. Primary load one has a strong peak in the evening, while the second load is more even throughout the day (see Figure 2.16), which makes PV a good generation option when the village load is low relative to the more stable factory load. The other interesting result is that the diesel genset-only configuration is optimal at low combined load levels only, which supports the claim that windpower is an economical part of the generation mix, even with lower wind speeds. 
Figure 2.12: Optimal system by load profile (PL 1 versus. PL 2)

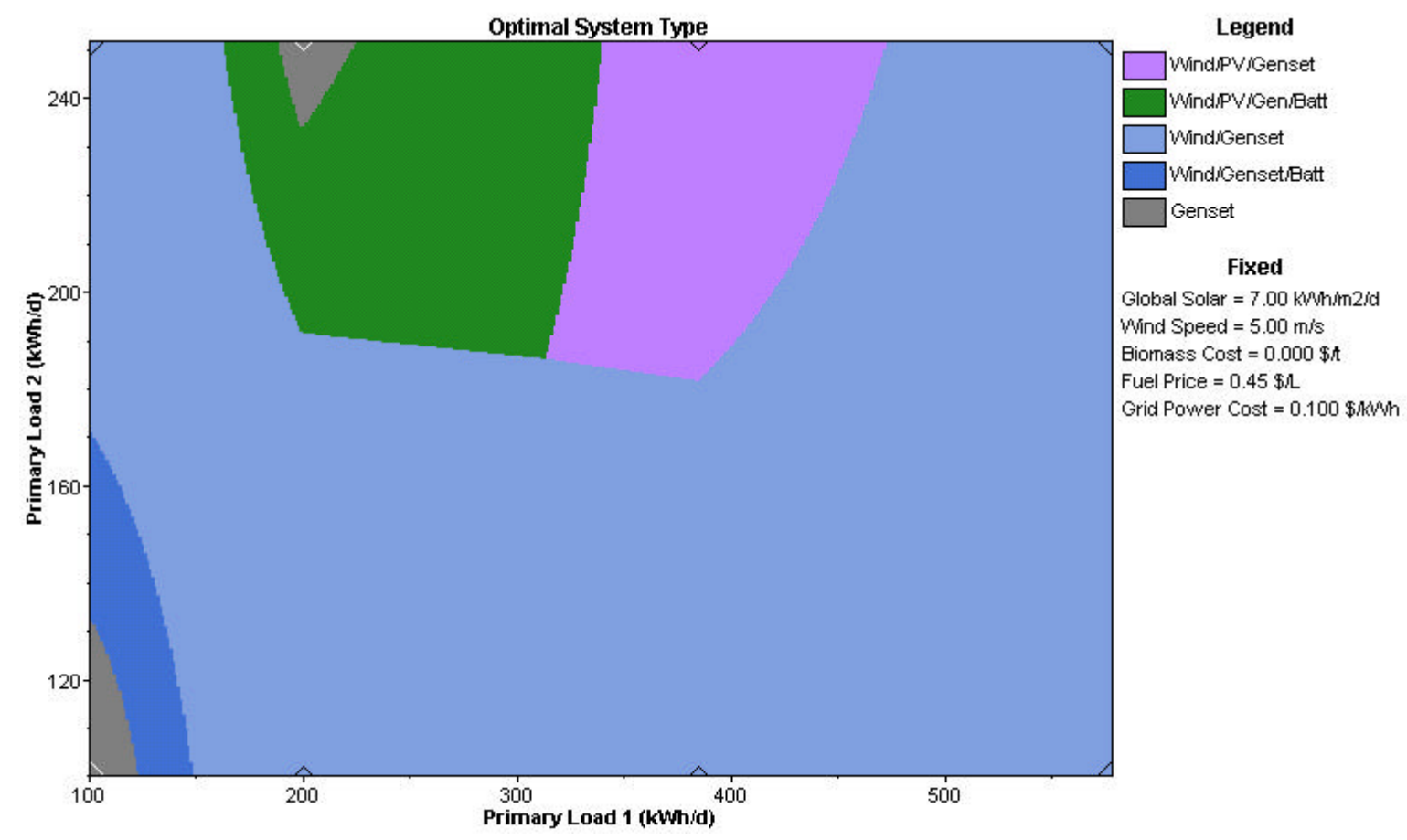

\subsubsection{Breakeven Grid Distance}

A hybrid system is in direct competition with the grid supply of electricity. To measure the decision point between the two, the breakeven grid distance - defined as the distance from the grid where the net present cost of extending the grid is equal to the net present cost of the hybrid system - is calculated. Figure 2.13 displays the results for the Khadir model.

Figure 2.13: Breakeven grid extension distance vs. grid power cost

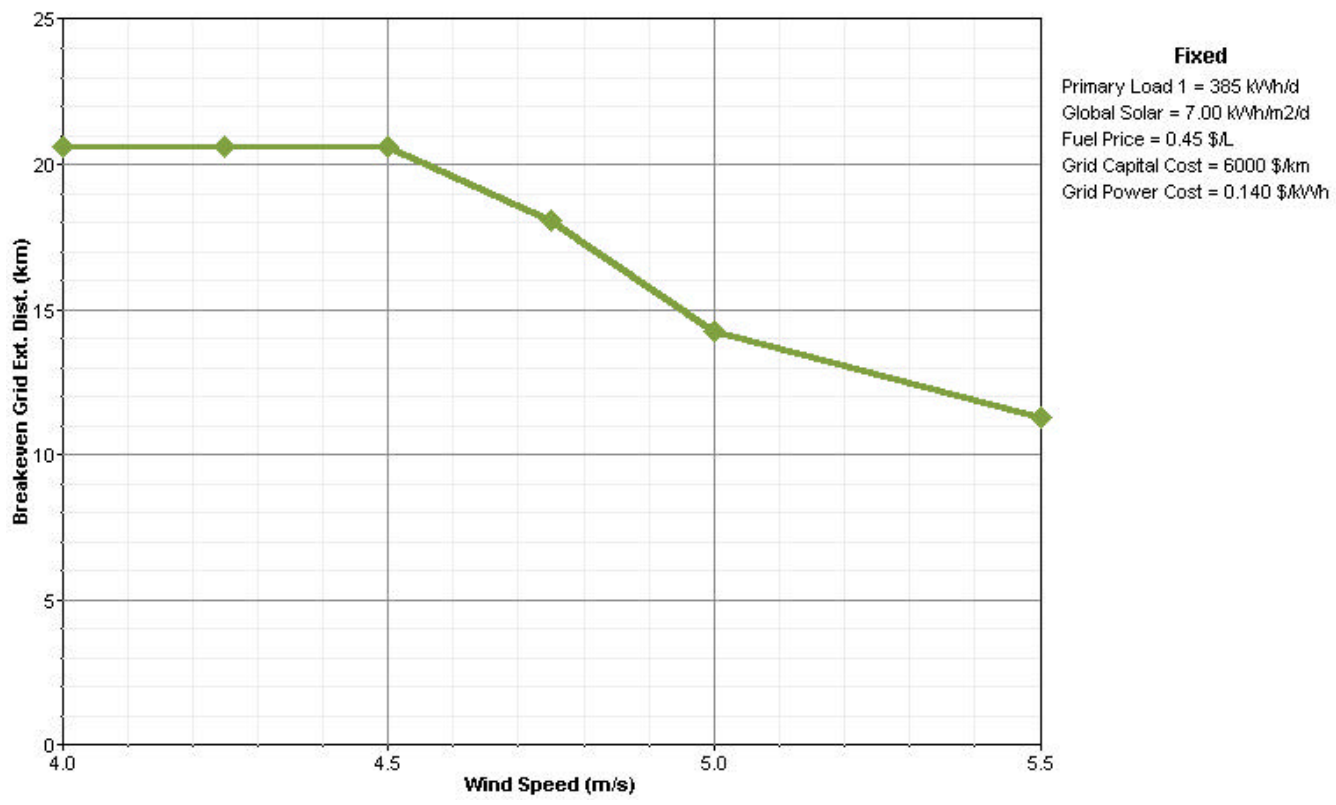


Setting the sensitivity variables for grid capital costs at $\$ 6000 / \mathrm{km}$ and grid delivered power at Rs $7 / \mathrm{kWh}$, the breakeven distance is $11 \mathrm{~km}$ for $5.5 \mathrm{~m} / \mathrm{s}$ wind regimes. In other words, the grid would have to be within $11 \mathrm{~km}$ for it to be a lower cost option than a wind-diesel hybrid system. The breakeven distance, however, is highly dependent on the assumed price of delivered power. The tariff costs and the real marginal cost of power delivery are widely different in Gujarat rural areas. The lower figure of Rs3/kWh, claimed by the GEB, yields a breakeven distance of $32 \mathrm{~km}$ for $5.5 \mathrm{~m} / \mathrm{s}$ wind speeds. For both power cost assumptions, the actual long grid length of more than $30 \mathrm{~km}$ that is maintained by the GEB to service Khadir makes hybrids a viable option, especially if the grid is significantly damaged in the future, as frequently happens during the cyclone season.

One often-used argument against employing hybrids in Khadir is that the grid is already in place and is therefore a sunk cost. To test the economic implications of accepting this premise, the Khadir model was used to test several different levels of grid capital costs. The first scenario examined a low figure of $\$ 1000 / \mathrm{km}$ for grid installation, which approximates the total needed to maintain the existing grid at low levels of service with high line losses and transformer failure. These results were then compared to medium and high grid investment regimes, $\$ 4000 / \mathrm{km}$ and $\$ 8000 / \mathrm{km}$, respectively. Figure 2.14 shows the results for each capital cost variable across various grid power cost assumptions.

Figure 2.14: Breakeven grid extension distance vs. grid power cost

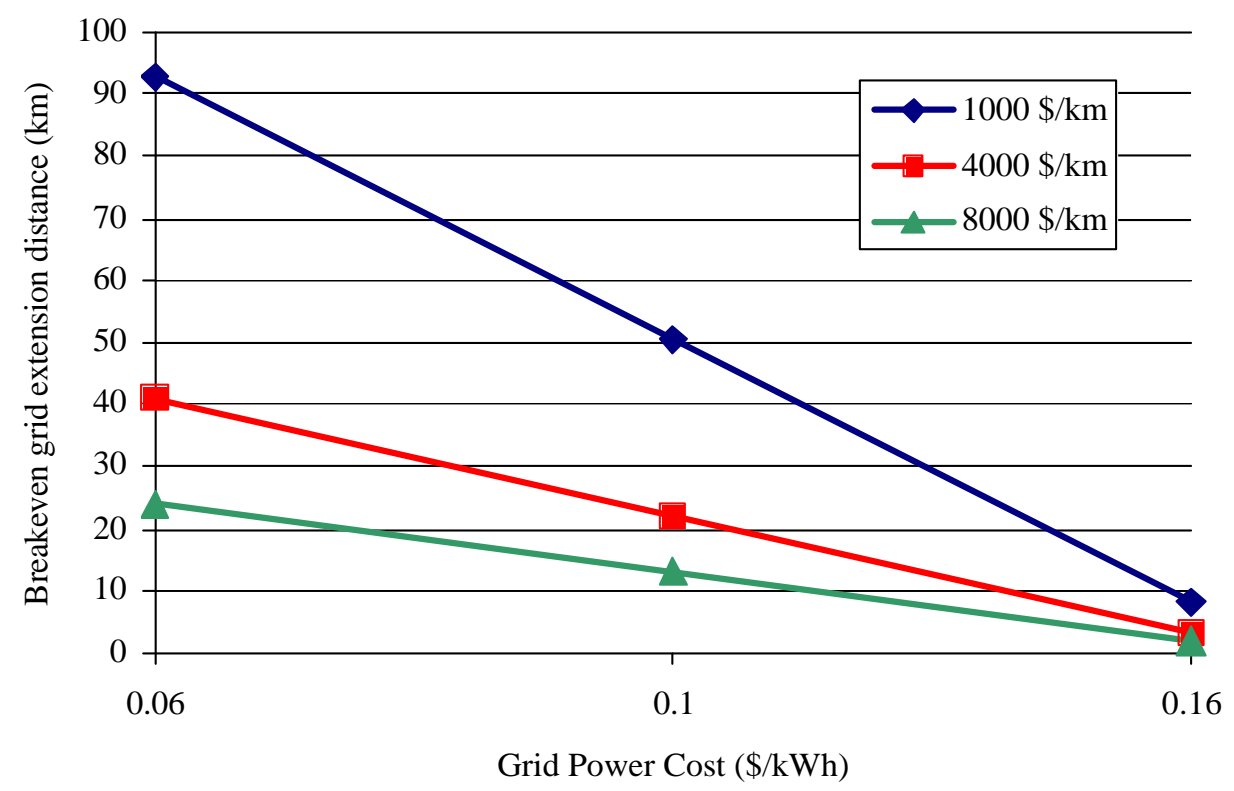


For the top line, representing the O\&M cost of $\$ 1000 / \mathrm{km}$, the breakeven distance is very high - 90 plus km with low power cost assumed; however, like the $\$ 4000$ and $\$ 8000$ capital cost lines, it converges to less than $10 \mathrm{~km}$ when the power costs reach $\$ 0.16 / \mathrm{kWh}$ (Rs $8 / \mathrm{kWh}$ ). This result demonstrates that the most important variable in determining the grid's competitiveness with hybrids is the real long-term marginal costs of delivered power. The analysis of grid-delivered power to rural areas in Gujarat in Section 2.5.8 shows that real marginal costs are more than double busbar energy expenses, or well above $0.10 \$ / \mathrm{kWh}$, and thus existing grid investments do not necessarily preclude the use of hybrid systems in the future if unit power costs are high. The argument is even stronger when you consider the constant damage that the line in Kachchh sustains as a result of cyclones, which strike the Rann about every three to four years, necessitating a nearly complete reconstruction of the line.

\subsubsection{Fuel Price Sensitivity}

The price of diesel fuel has a direct influence on the costs of energy, but the relative effect is dependant on the wind regime and how much turbine capacity is installed. Table 2.9 shows the changes in cost of energy (COE) as the fuel price escalates with $5.5 \mathrm{~m} / \mathrm{s}$ average wind speeds.

Table 2.9: Fuel price increases and changes in cost of energy

\begin{tabular}{|rr|rr|}
\hline $\begin{array}{c}\text { Fuel Price } \\
(\$ / \mathrm{L})\end{array}$ & $\%$ Increase & $\begin{array}{c}\mathrm{COE} \\
(\$ / \mathrm{kWh})\end{array}$ & $\%$ Increase \\
\hline \hline 0.3 & -- & 0.186 & -- \\
0.4 & $33.3 \%$ & 0.210 & $12.9 \%$ \\
\hline 0.5 & $25.0 \%$ & 0.234 & $11.4 \%$ \\
0.6 & $20.0 \%$ & 0.258 & $10.3 \%$ \\
\hline
\end{tabular}

The COE grows less than half as fast as fuel prices; therefore, a hybrid system provides a buffer to oil price shocks in rural communities. Remote locations and irrigators that might otherwise be at the mercy of the world price for oil can reduce their exposure vulnerability with a hybrid system, especially if the amount of unserved load is allowed to increase, (i.e. the diesel genset can be used less frequently).

To understand the cost savings from wind turbines in hybrid systems more directly, Figure 2.15 shows the COE savings for different diesel price levels over a range of wind speeds. The different diesel cost curves converge at low wind speeds because the turbines contribute little 
or nothing in the way of displacement; as wind speeds rise the savings increase, especially when oil prices are high, as shown by the $0.6 \$ / \mathrm{L}$ line, the uppermost on the chart.

Figure 2.15: Cost of energy savings vs. wind speed for four diesel price levels $(\$ / \mathrm{L})$

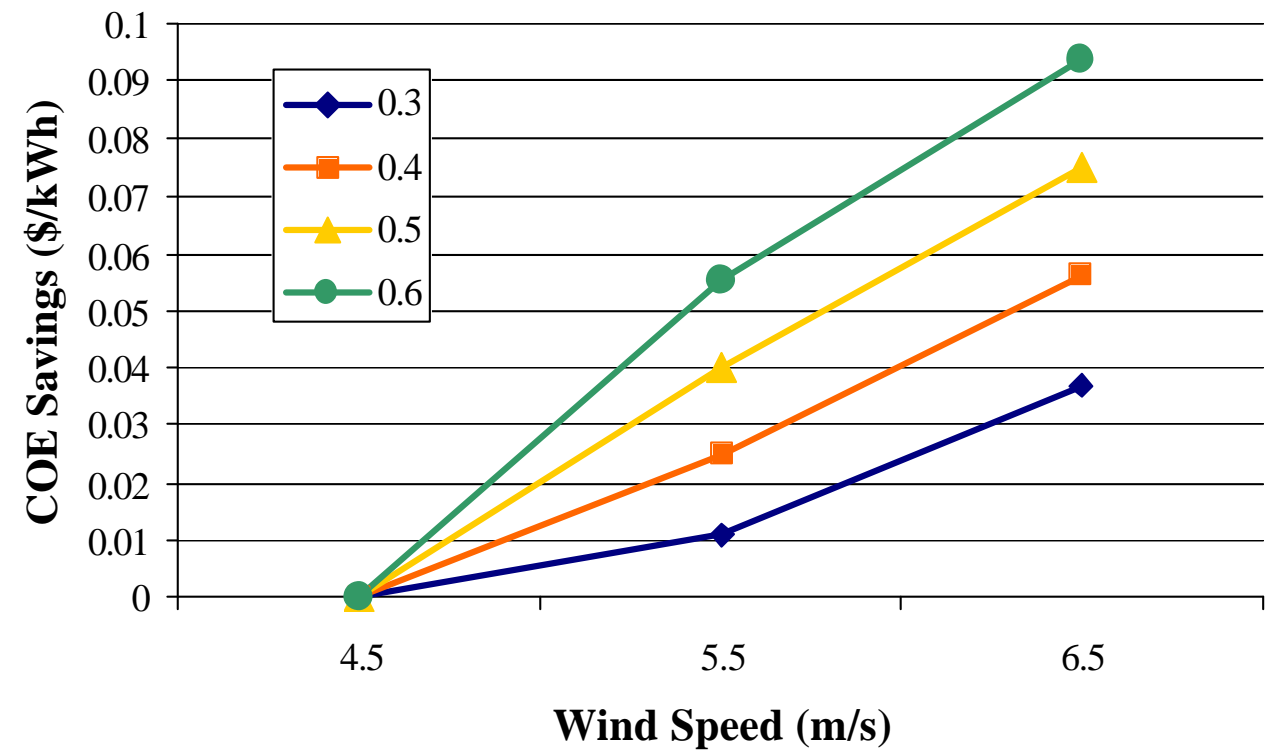

\subsubsection{Analysis and Implications}

The optimisation model employed in this study allows for the selection of a hybrid system under uncertain conditions by using sensitivity analysis. Thus, robust conclusions can be drawn about the chosen system. The total cost of the optimal hybrid system would be approximately $\$ 367,000$ in NPC terms at $10 \%$ real interest rates, which translates into a cost of $\$ 0.22 / \mathrm{kWh}$ or Rs $10.66 / \mathrm{kWh}$. The total upfront capital needed is $\$ 121,000$ for the wind-diesel system. Interestingly, the lower initial cost of the diesel-only system, $\$ 48,000$, is much higher for the total life cycle of the project and therefore results in a higher cost per unit of energy (COE).

To make the investment in the hybrid system economically feasible, a careful breakdown of the different market segments is needed. A simplified business model would spread a projects cost over each of the families in the village. Assuming 300 households per village, the total capital cost per family would be $\$ 403$. This is equal to $\$ 65$ in payments per year at a real interest rate of $10 \%$ and maturity of 10 years. Energy charges would be in the range of Rs 150/month per household, again with uniform charges regardless of income and consumption. Under these 
assumptions the village may be able to pay for the system itself, especially if long-term finance with preferential rates is made available by government or development banks. The lengthy payback periods, however, may make it difficult for a private company to justify the capital expenditure without special tax or service incentives under the flat capital and energy recovery scheme detailed above.

A more realistic scenario would take advantage of market differentiation by charging more for energy during peak times and for power that cannot be interrupted. Certainly, the tariffs recoverable from the economic growth enabled by reliable power supply, i.e. the factory and the resulting support jobs that it creates, would be the key to system profitability. This tariff approach is used by most large utilities and would have a more attractive commercial profile. The capital and energy costs could be spread out depending on a household's income and power consumption, with low rates and a guaranteed supply for basic service load (lighting, radio and fans, for example), while the small industries and wealthier consumers would pay the higher rates and effectively pay down the capital investment. Figure 2.16 shows the differentiation of the demand into four components.

Figure 2.16: Demand profile for Khadir Village (hour v. kW) and demand differentiation

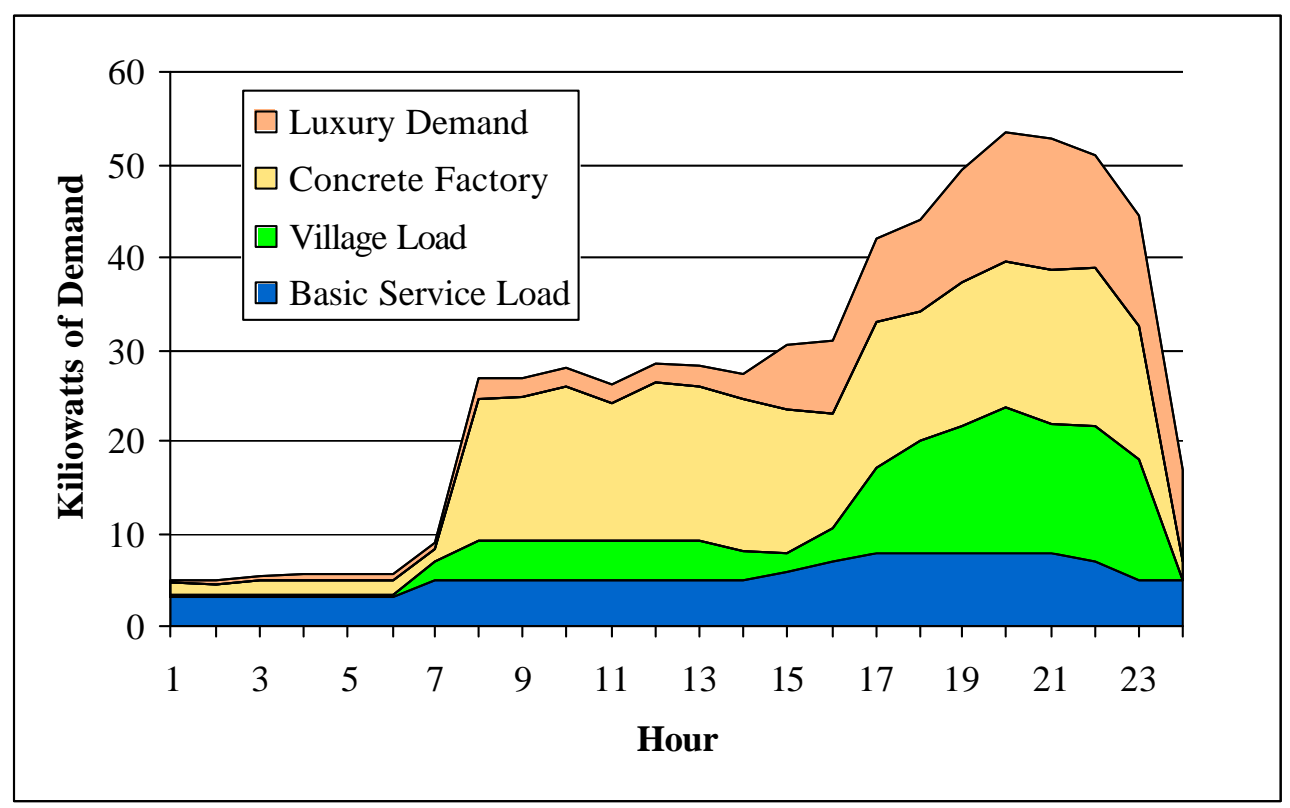

The lowest category on the graph is the basic service load as estimated by the author, which includes the domestic load of the poorest households and would likely need to be subsidised. The second category represents the commercial use of power in the village, such as shop users 
and the third block of demand is from the concrete factory. The tariff rates for these two categories should reflect their 'value-add' to the economy and thus would pay for most of the operating and capital costs of the hybrid system. The fourth section is the peak demand, consisting mostly of commercial and wealthy domestic users for 'luxury' appliances, such as TVs, refrigerators and satellite receivers. Some of the peak load can be shifted, particularly the portion used by irrigation pumps, to other times and the remainder should be charged a higher tariff to reflect the incrementally higher costs of supplying it and to offset the remainder of the capital investment.

Innovative tariff structures and the commercial response of the incumbent firm (GEB) are topics which require more research; however a detailed breakdown of implementation and business planning remain outside the scope of this study. One danger that historically has plagued rural power systems is the 'cherry-picking' of the valuable loads by the grid operator or dominant firm, leaving only low value domestic loads which are unprofitable to serve. Careful regulation or target subsidies will be needed to prevent this market segmentation.

\subsubsection{Village Load Factor and Unserved Load}

To examine the capacity utilisation of the selected hybrid system versus a grid-connected system, the load factor (LF), defined as ratio of average power to maximum demand, can be calculated, using:

$$
\text { Load factor }=\frac{\text { Units consumed in a given period }}{(\text { Maximum demand }) \times(\text { hours in period })}
$$

For the optimal system in Kachchh using the baseline assumptions, the LF is equal to 0.437 , meaning that the system is only used at $43 \%$ of the maximum demand each year. However, the LF is somewhat misleading for hybrid systems because a maximum unserved load, $20 \%$ in this case, is allowed for in initial system design and thus reduces the maximum demand if not enough power is available, (e.g. when the wind speed is low). After making the $20 \%$ adjustment to maximum demand, the LF climbs to a respectable 0.55. For comparison, Pabla cites an LF of 0.36 in diversified loads in districts with industrial units in Punjab (Pabla, 1997).

To understand the load profile of the village under the modelling assumptions, the duration curve is a useful graphical tool, and is shown in Figure 2.17. The maximum demand is only above $50 \mathrm{~kW}$ for $8.5 \%$ of the year, or 753 hours, and this is due to the heavy late evening 
demand of primary load 1 . However, it is during these periods when the unserved demand is greatest, as shown by the top, left-hand portion of the duration curve in Figure 2.18.

Figure 2.17: Duration curve of the total primary load, (one year $=8760$ hours)

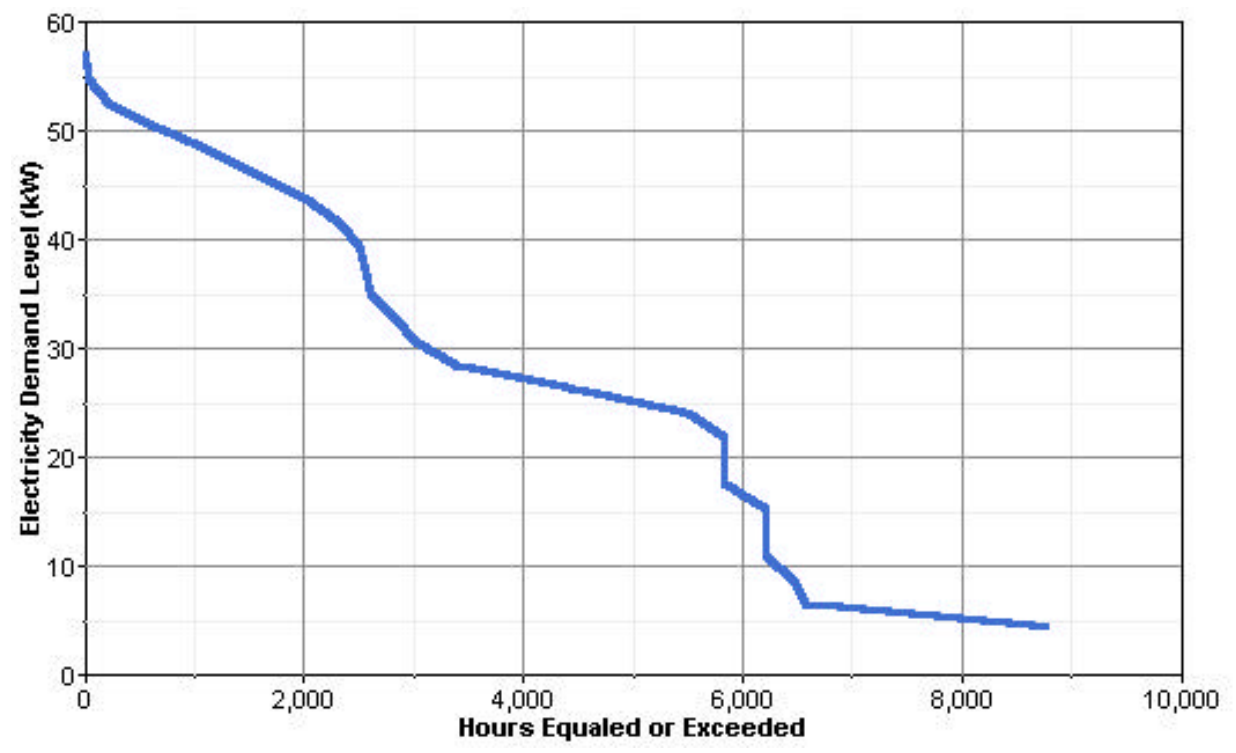

Figure 2.18: Unserved load duration curve

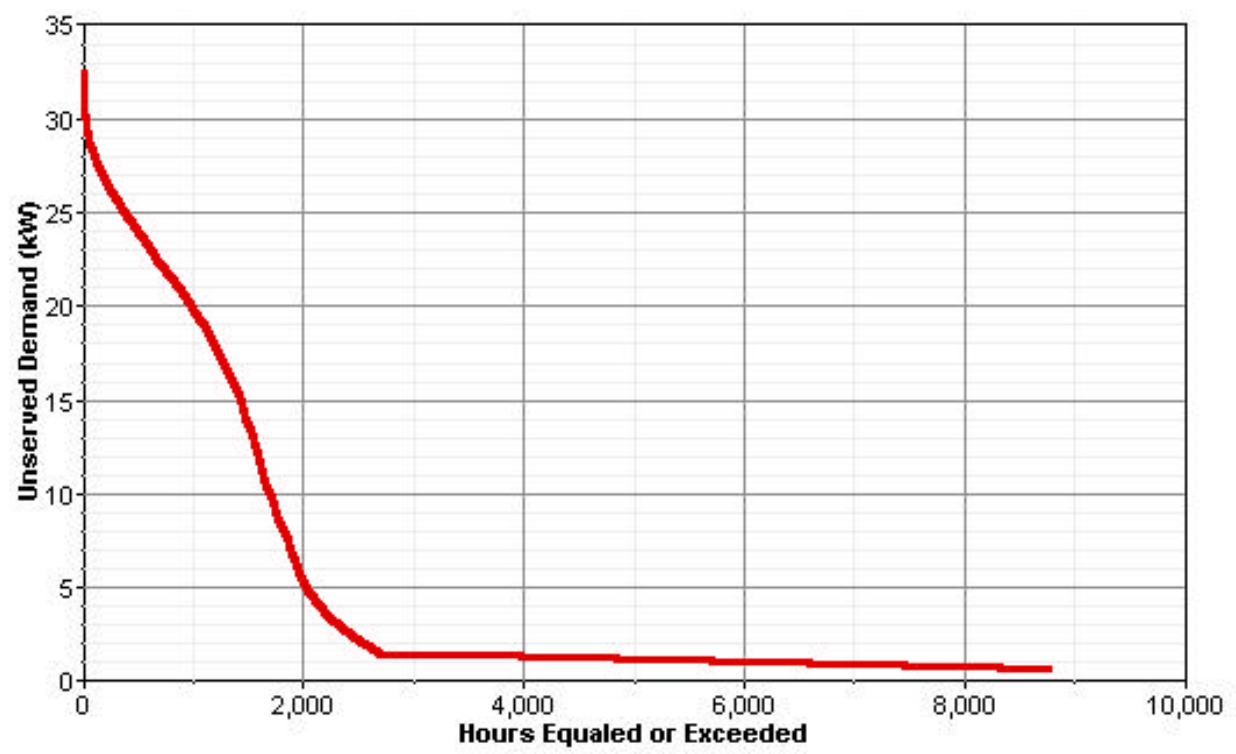

The important conclusion that can be drawn is that if the village is able to bear a $20 \%$ unserved fraction of energy, then capital and energy costs can be reduced and thus the project will be more viable to finance. The strength of the hybrid DG system is that loads that cannot be cut off, such as hospitals and small industries, can be reliably maintained by the diesel, even if the wind speeds are low. Conversely, the interruptible nature of most domestic loads and water pumping can enable a much leaner system capacity and reduce costs. 


\section{CONCLUSIONS}

The ongoing process of power sector reform, new small-scale generating technologies and a better understanding of rural energy needs has created an opportunity for the rural power situation. One solution is to use combinations of renewable and conventional power technologies, or hybrid systems, to provide electricity in remote locations where it is too expensive to extend the grid, or where the grid cannot operate without high losses.

This paper presents an economic and operational case study of a hybrid system in the Khadir region of the north-eastern Kachchh district in Gujarat, India. Local resources, economic conditions, energy needs, and proximity to the electricity grid are used to form modelling input assumptions which are tested over a wide range of sensitivities. The results show that a winddiesel hybrid system can operate effectively in Khadir, provided annual average wind speeds are above $4.75 \mathrm{~m} / \mathrm{s}$.

\subsection{Additional Benefits of Distributed Generation Systems}

Competitive small-scale systems may provide an opportunity to open up the electricity market to competition from the bottom up and provide job opportunities and economic growth for remote rural areas. It may also bring additional benefits to the operation of the existing electricity system and the wider economy as discussed below.

\subsubsection{Transmission Constraint Reduction and Postponed Generation Investment}

The remote nature of the Khadir grid system has meant that large line losses are incurred during peak demand periods as more current is passed through the limited infrastructure. The addition of local generation can eliminate this problem.

Distributed generation allows utilities to delay investments in new generation, transmission and distribution capacity, and reduces both variable costs and the value of deferring investments (Hoff, Wenger, and Farmer, 1995). For the hybrid system operators, the modular nature of the generation equipment also allows for delayed investment. DG systems can grow in a graduated way as demand expands. For example, the Khadir hybrid model uses a $50 \mathrm{~kW}$ wind turbine and a $25 \mathrm{~kW}$ diesel genset to provide power for a $385 \mathrm{kWh} /$ day demand. As this demand grows to $1000 \mathrm{kWh} /$ day, the new optimal system is a two wind turbine system with a 
$50 \mathrm{~kW}$ genset. This upgrade can be made predictably as demand rises instead of having expensive capital not being fully utilised if all the generation had been built at the beginning of the project.

\subsubsection{Small Wind Turbine Technology and Local Manufacture}

No Indian firms are constructing high quality wind turbine generators (WTGs) for small-scale applications of 10-100 kW. However, the successful demonstration of hybrid systems in a remote Indian location will begin to create a market pull for the technology. A growing small turbine market would probably result in joint ventures between U.S. and E.U. firms and their Indian counterparts, just as it has in the utility-grade WTG market. These partnerships would result in significant cost reductions as companies begin to take advantage of low Indian labour rates - for example, large turbines are 10-20\% cheaper to produce in India (Patil, 2003).

\subsubsection{Local Control and Incentives}

From an implementation standpoint, it is postulated that local control will increase the ability to manage the DG system profitably and decrease theft and corruption. Depending on the system design, NGOs, village councils (panchayats), and private distribution companies are all good candidates for running a hybrid system (Holland et al., 2001). This has been the case in Bangladesh, where a branch of Grameen Bank has successfully operated scores of rural energy projects (Biswas, Bryce, and Diesendorf, 2001) and a PV-based micro-utility system was successful in a rural market in Bangladesh (Ibrahim et al., 2002).

In Mondu, Indonesia, a $1.5 \mathrm{~kW}$ wind turbine installed last year by Winrock International under the auspices of a USAID program is benefiting villagers with power that enhances local income generation. The turbine is used to power a refrigeration unit which produces ice for fish preservation. Without the ice, the fish had to be dried or sold to middlemen who could freeze it and transport it to the nearest market, about two hours away by motorcycle. The sale price for dried fish was $350400 \mathrm{Rs} / \mathrm{kg}$, while the middlemen traders offered $700 \mathrm{Rs} / \mathrm{kg}$ for fresh fish. 'With the advent of their own refrigeration service and the ice it provides villagers are able to bring their own catch to market. Using this improved method of marketing, the price paid for fresh fish is approximately $1500 \mathrm{Rs} / \mathrm{kg}^{\prime}$ (AWEA, 1998):2). 
In Khadir, the provision of power for refrigeration may enable storage of dairy products for later sale. Better power supplies can also support local industries, such as the concrete plant in the case study or handicraft industries for cash income generation.

\subsubsection{Carbon Emission Reduction}

The use of hybrids in remote areas can help to reduce the use of diesel gensets and therefore reduce the total carbon emissions of the local energy system. In the case of the Khadir hybrid model, the level of emissions is most dependent on the total demand and the wind speed. Figure 3.1 shows that at high wind speeds $(5.5 \mathrm{~m} / \mathrm{s})$ carbon emissions are cut by $40 \%$ compared to low wind speeds where no diesel is displaced by windpower.

\section{Figure 3.1: Carbon emissions versus wind speed}

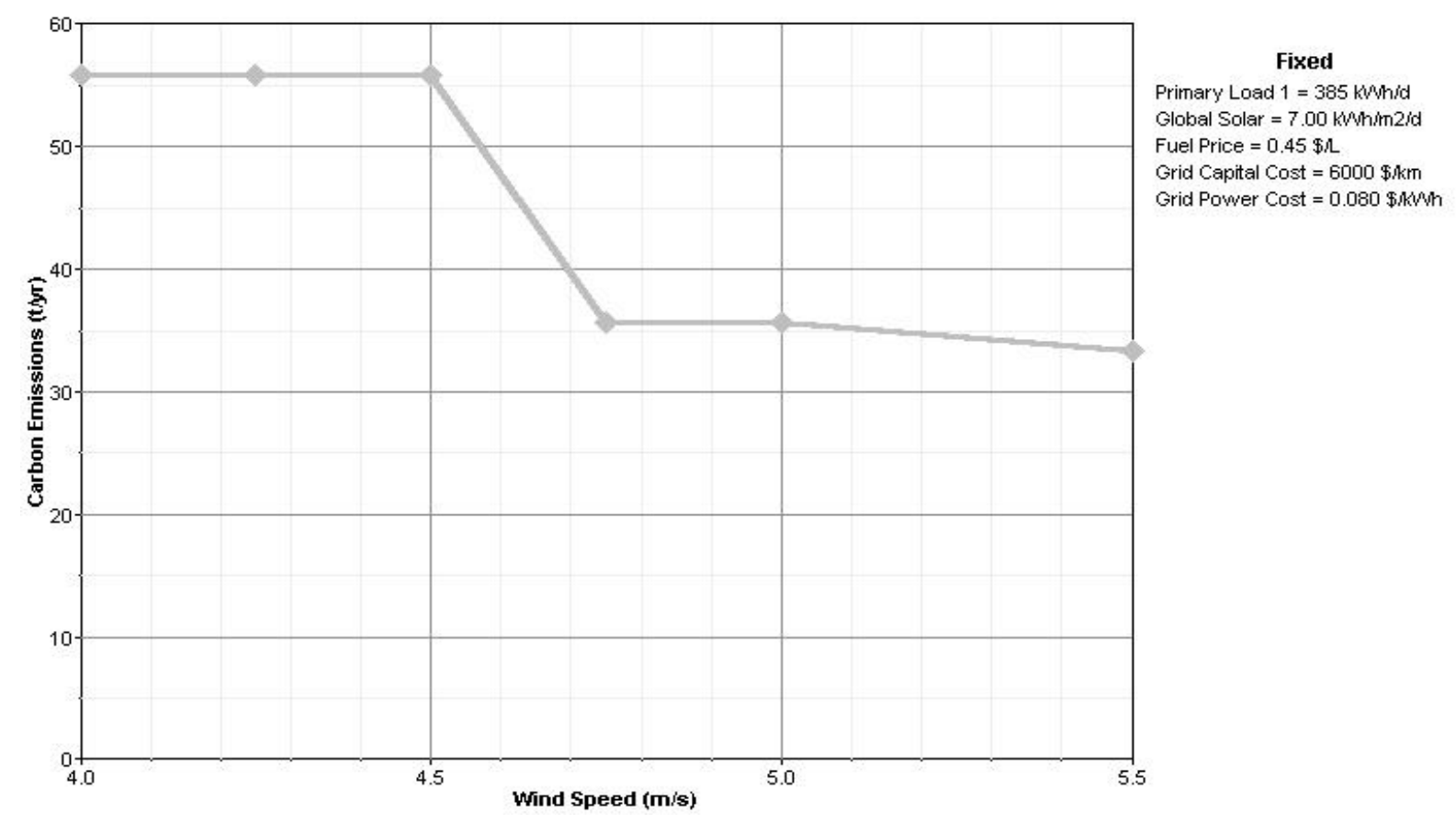

For a more complete understanding of carbon emission dynamics as wind and loads change, the combination of three variables is represented with a colour gradient map, as in Figure 3.2. The upper left-hand corner of the mapping is the highest carbon emissions situation - low wind speeds and high power loads. The opposite is true in the lower right-hand corner, where high wind speeds displace diesel use. 
Figure 3.2: Carbon emissions by electricity demand load and wind speed dependence

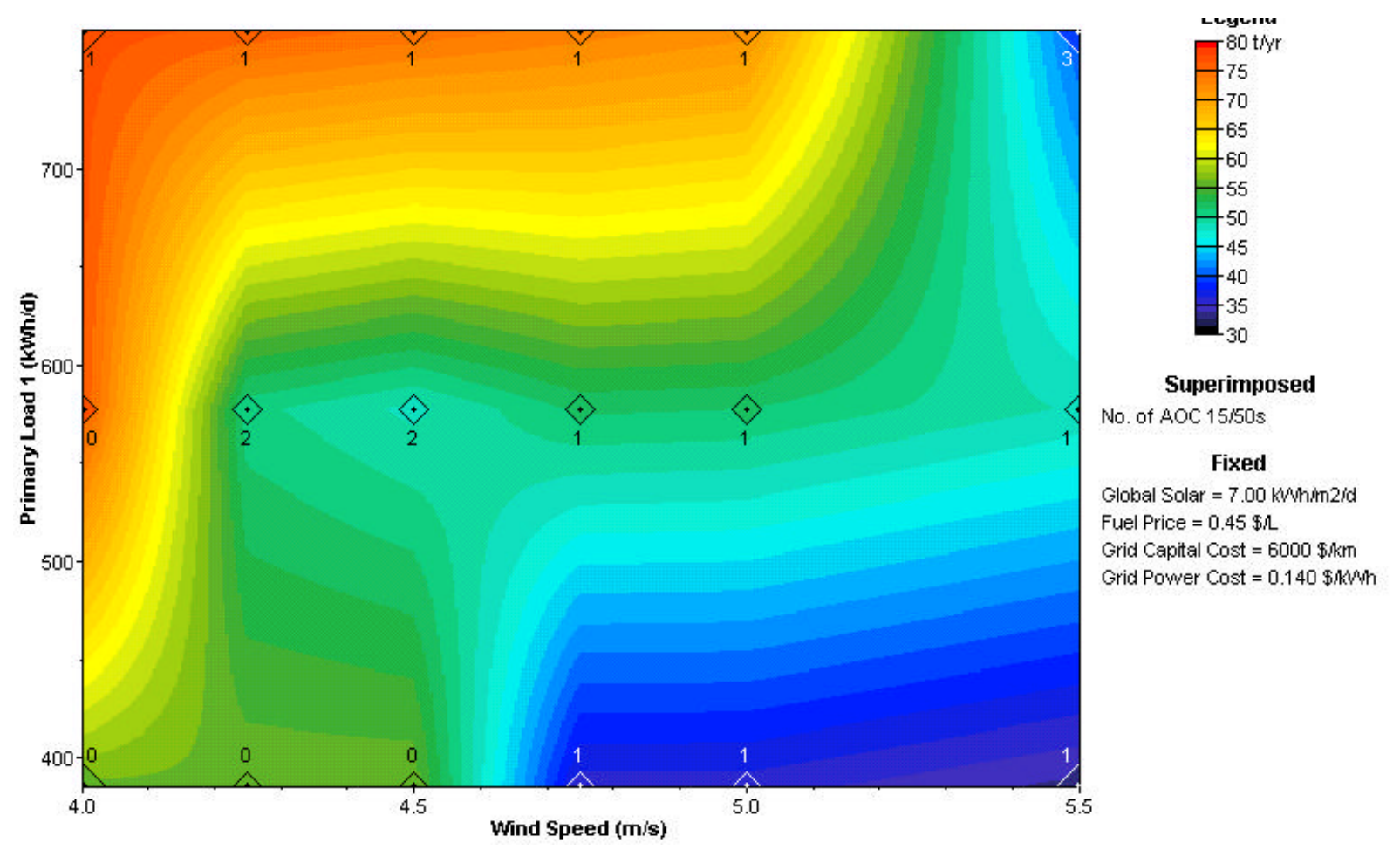

The discontinuities in the mapping result from the step attribute of wind turbine and diesel additions to the system as demand grows, meaning turbines and gensets are added in 25 to 50 $\mathrm{kW}$ increments. The superimposed numbers on the figure indicate the number of $50 \mathrm{~kW}$ WTG for the optimal system at the given conditions. The two-turbine 'island' in the middle of the mapping is the result of an increased load with adequate wind resources which prevents the need for more diesel capacity until the load grows even larger. Also, diesel engines cannot run below $30 \%$ capacity, unlike WTGs which can run across their entire nameplate capacity.

\subsection{Barriers to Hybrid Energy Systems in Gujarat}

Capturing the benefits from hybrid projects in Gujarat faces several serious obstacles:

i. Low, subsidised tariffs have reduced the incentive to seek alternatives in rural areas. Farmers have had to pay so little for power, and domestic users have been able to steal free power for so long that the implementation of a pay-for-service model will have to overcome an expectation of free power. The tacit and explicit contracts of consumers to pay for service and the GEB to deliver quality service have been broken. As Morris explained, 'they pretend to supply electricity and the customers pretend to pay.' (Morris c, 2002) 
ii. No local capacity exists for maintenance or finance of small-scale power systems. RE projects and therefore hybrids require significant upfront capital investment, and the credit market does not exist for such projects. All financing is currently coming from NGOs, development banks or subsidised loans from IREDA/GEDA. Complicating the lack of credit in the sector is the large amount of regulatory uncertainty that pervades all new power projects. The basic market structure has not been determined in Gujarat and thus credit risk is pushed higher.

iii. Hybrid projects suffer from a lack of economies of scale. High set-up costs and the need for specialised engineering skills to build hybrid systems mean that many projects will need to be lumped together in order to reduce costs. Incentives from IREDA and REC may also not be enough to overcome low tariffs that can be charged to rural consumers, and the projects will remain financially out of reach for communities.

iv. The MNES discourages use of diesels because of pollution concerns (Chaurey, 2002), and thus may exclude hybrid projects. In addition, the GEB will probably not encourage hybrids because it would allow new entrants who may eventually cherrypick best loads - the same reason that captive power is discouraged. The GEB will not encourage a small IPP with the ability to wheel power, such as a hybrid project, because it breaks their monopoly, as evidenced by the GEB refusal to buy electricity at long-run marginal cost even though power shortages exist.

\subsection{Conclusions and Scope for Further Research}

The cost of energy in the fossil fuel-based centralised power stations consists of the generation, transmission and distribution costs, whereas in the decentralised power generating system energy cost is primarily the generation cost. Conventional centrally-managed approaches to electricity distribution have been expensive and unsustainable (Holland et al., 2001) and the financial analysis presented in this paper makes the case for a distributed approach in remote, rural areas using hybrid power systems.

This paper set out to answer the question of whether hybrids would be a cost-effective way of providing energy services in rural Gujarat. In the case of Khadir, the answer is yes and thus 
more research is needed to flesh out the business plan and regulatory steps that will be needed to overcome the financial and institutional barriers mentioned in section 3.1. The scope for DG to be a market opening and innovative force in the Indian electricity sector is potentially vast and hybrid systems should not be thwarted to keep the SEB insulated from competition. The rural sector needs reliable power, and hybrids can fill the void in many situations. The most urgent need is to create an enabling regulatory scheme for small-scale generators and reduce the subsidies to boost demand-pull for rural power. 


\section{APPENDIX. RESEARCH METHODS}

This appendix discusses the research methods used to study the feasibility of distributed, hybrid electricity generation systems in Gujarat, India. The first step was an overarching literature review for the electricity sector in India generally and Gujarat specifically. Special attention was paid to the political economy factors present and, on the technical side, a range of distributed generation (DG) systems were examined to assess their suitability for the area. Once this had been completed, fieldwork in India was undertaken to interview key participants in the small-scale energy sector and to gain information about the regulatory regime in Gujarat and how it is likely to evolve with regard to DG systems as reform efforts go forward. The fieldwork also was used to collect supply and demand side information that would be used for the model inputs for the energy supply simulation in Khadir.

\section{Pricing and Resource Information}

Cost and resource information in Khadir was not readily available in most cases, and had to be estimated based on figures obtained near the case study site. For example, the wind data from three sites in Kachchh near Khadir collected by the MNES were used to extrapolate the average wind speeds in the village being considered in Section 2 (see Table 2.6). To account for the increase in wind speed with height above the ground, the speed at the turbine height was calculated using the formula (Gipe, 1999):

Ave. Wind speed at $h_{2}=\left(\right.$ Ave. Wind at $\left.h_{1}\right)\left(h_{2} / h_{1}\right)^{1 / 7}$

Where:

$\mathrm{h}_{2}=$ the height of the turbine installed

$\mathrm{h}_{1}=$ the height of the anemometer

\section{HOMER Model Description}

HOMER stands for the Hybrid Optimisation Model for Electric Renewables and was developed by the National Renewable Energy Laboratory in Golden, Colorado, USA. HOMER was developed as a hybrid system design tool 'accurate enough to reliably predict system performance, but simple and efficient enough to conveniently evaluate a large number of 
design options' and then rank the results to find the optimum configuration (NREL, 2003). HOMER identifies the least cost system for supplying electricity to remote loads by performing hourly simulations of thousands of potential power systems and rank ordering them by life-cycle costs. It also performs sensitivity analyses to evaluate the impact of a change in any of the input parameters and provides both annual and hourly outputs in tabular and graphic form. Hybrid system design is made difficult by the intermittency of renewable resources, the need to match electrical supply and demand, and the large number of potential component size combinations. HOMER provided an excellent platform on which to test hybrid viability in Khadir and eliminated the need to spend time building an optimisation model from scratch. The HOMER model is also well tested and validated (Lilienthal, Flowers, and Rossman, 1995). The formulae details for the three most important output variables of the model are below.

\section{Net Present Cost}

The net present cost is the discounted value of all the cash flows needed to operate and purchase the hybrid system over its lifetime of 20 years. The following formula was used:

$$
C_{N P C}=\frac{C_{\text {axntot }}}{\operatorname{CRF}\left(i, R_{p r o j}\right)}
$$

Where:

$$
\begin{aligned}
& \mathrm{C}_{\text {ann,tot }}=\text { total annualised cost }(\$ / \mathrm{yr}) \\
& \mathrm{CRF}()=\text { capital recovery factor } \\
& \mathrm{i}=\text { interest rate }[\%] \\
& \mathrm{R}_{\text {proj }}=\text { project lifetime }[\mathrm{yr}]
\end{aligned}
$$

The first variable is the total annualised cost of the system, which is equal to the sum of each component's annual operating cost plus its annualised capital cost over its useful lifetime plus the annual fuel cost, if applicable (NREL, 2003). By adding the results for all components, the total annualised cost can be calculated, $\mathrm{C}_{\mathrm{ann}, \mathrm{tot}}$. The capital recovery factor is a function of the real interest rate and the project lifetime and is used to discount the cash flows to time zero. 


\section{Cost of Energy}

The cost of energy $(\mathrm{COE})$, in $\$ / \mathrm{kWh}$, is the level of tariff needed to recoup the NPC of the hybrid project. However, differential tariff structures can be used to aid poor clients, so the COE figure is only indicative of the median level of charges that must be supported by the host community:

$$
C O E=\frac{C_{o x n t o t}}{E_{p r i m}+E_{d \ell f}}
$$

Where:

$$
\begin{aligned}
& C_{\text {ann,tot }}=\text { total annualised cost of the system }[\$ / y r] \\
& E_{\text {prim }}=\text { primary load served }[\mathrm{kWh} / \mathrm{yr}] \\
& \mathrm{E}_{\text {def }}=\text { deferrable load served }[\mathrm{kWh} / \mathrm{yr}]
\end{aligned}
$$

The two loads, $E_{\text {prim }}$ and $E_{\text {def }}$, are based on village per capita estimates, as explained in Section 2 , and are tested across a range of values to assess the robustness of the hybrid to grow as demand expands.

\section{Breakeven Grid Distance}

The breakeven grid distance is calculated to indicate the length of grid extension and gridsupplied power that is financially equivalent to the service provided by the optimal hybrid system. This calculation relies on three input variables, grid capital cost, grid operation and maintenance $(\mathrm{O} \& \mathrm{M})$ costs and the price of grid-supplied power. The total load is also tested for variability.

$$
D_{g r i d}=\frac{C_{N P C} \cdot \operatorname{CRF}\left(i, R_{p r o j}\right)-c_{p o w e r} \cdot L_{t o t}}{c_{c a y} \cdot \operatorname{CRF}\left(i, R_{p r o j}\right)+c_{o w}}
$$

Where:

$\mathrm{C}_{\mathrm{NPC}}=$ total net present cost of the standalone power system (hybrid) [\$]

$\mathrm{CRF}()=$ capital recovery factor 
$\mathrm{i}=$ real interest rate $[\%]$

$\mathrm{R}_{\text {proj }}=$ project lifetime $[\mathrm{yr}]$

$\mathrm{L}_{\mathrm{tot}}=$ total primary and deferrable load $[\mathrm{kWh} / \mathrm{yr}]$

$\mathrm{c}_{\text {power }}=$ cost of power from the grid $[\$ / \mathrm{kWh}]$

$\mathrm{c}_{\mathrm{cap}}=$ capital cost of grid extension $[\$ / \mathrm{km}]$

$\mathrm{c}_{\mathrm{om}}=\mathrm{O} \& \mathrm{M}$ cost of grid extension $[\$ / \mathrm{yr} / \mathrm{km}]$

\section{Conclusion and Critical Remarks}

Life-cycle cost analysis calculates the total expected costs of ownership over the lifespan of the system. LCC allows the direct comparison of the costs of alternative energy systems, such as hybrids with grid power. 'The cost minimization approach eliminates the need to measure the value of the benefits provided and assumes that a given level of demand must be met at a uniform quality of supply. The question then becomes simply selecting the lowest cost method of supplying rural electric consumers. '(Munasinghe, 1987: 61) ?? not in list of references). By not evaluating the social benefits, the model is much simpler to execute, but does not capture the entire extra gain from hybrids in rural areas. In other words, the results underestimate the total returns from implementing a hybrid system, which methodologically is a better error to make than overstated false positive.

A common critique of financial analysis of renewable projects, especially ones that have never been built in the area, is that factors during implementation will be more expensive and project approval more difficult than accounted for in the model. Although comparisons were made with similar projects to increase the reliability of the inputs and a study of the political barriers was accomplished, the results do not encompass all the relevant factors. However, the scope of the study did not focus on the implementation issues, but instead makes the case for further investigation, aiming to confirm the hypothesis that hybrids are a viable option for Khadir and rural, remote Gujarat in general. Other areas would have to be tested in a similar manner in order to improve the generalisability. 


\section{REFERENCES}

Ackermann, T., Söder, L. 2002. An overview of wind energy-status 2002. Renewable and Sustainable Energy Reviews 6 (1-2):67-127.

AGL. 1997. Comparison of Large Central and Small Decentralized Power Generation in India.

Golden, CO: Antres Group Ltd. and National Renewable Energy Laboratory.

Ashworth, John. 1996. Mining the Urban Waste Stream for Energy: Options, Technological Limitations, and Lessons from the Field. Washington, DC: USAID.

AWEA. 1998. Indonesia Wind Power Project. Wind Energy Weekly, American Wind Energy Association (824).

AWEA. 2002. Global Wind Energy Market Report. Washington, DC: American Wind Energy Association.

Bakos, G. C., and M. Soursos. 2002. Techno-economic assessment of a stand-alone PV/hybrid installation for low-cost electrification of a tourist resort in Greece. Applied Energy 73 (2):183-193.

Barely, C.D. 1996. Modeling and Optimization of Dispatch Strategies for Remote Hybrid Power Systems. Ph.D., Mechanical Engineering, Colorado State University, Fort Collins, CO.

Baring-Gould, Ian, C. Newcomb, D. Corbus, and R. Kalidas. 2001. Field Performance of Hybrid Power Systems. Paper read at WindPower 2001, at Washington, DC.

Barley, C.D., M.A. Meares, and L. Flowers. 1998. Feasibility of Hybrid Retorfits to Existing Diesel Power Plants in the Philippeans - Preliminary Analysis. Golden, Co: NREL.

Barnes, D. 1988. Electric Power for Rural Growth. Boulder, CO: Westview Press.

Beerbaum, S., and G. Weinrebe. 2000. Solar thermal power generation in India--a technoeconomic analysis. Renewable Energy 21 (2):153-174.

Bhave, A. G. 1999. Hybrid solar-wind domestic power generating system--a case study. Renewable Energy 17 (3):355-358.

Bialasiewicz, J.T., E. Mulijadi, S. Drouilhet, and G. Nix. 1998. Modular Simulation of a Hybrid Power System with a Diesel and Wind Turbine Generation. Paper read at Windpower '98, April, at Bakersfield, CA.

Biswas, Wahidul K., Paul Bryce, and Mark Diesendorf. 2001. Model for empowering rural poor through renewable energy technologies in Bangladesh. Environmental Science \& Policy 4 (6):333-344.

Bose, Sarmila. 1993. Money, Energy and Welfare: The State and the Household in India's Rural Electrification Policy. Delhi: Oxford University Press.

Brealey, S., and R. Myers. 2000. Principles of Corporate Finance. 6th ed. Boston: McGrawHill.

Carta, J.A., and J. Gonzalez. 2001. Self-Sufficient Energy Supply for Isolated Communities: Wind-Diesel Systems in the Canary Islands. The Energy Journal 22 (3):115-145.

CECL. 2003. Wind Power in India. Consolidated Energy Consultants Limited 2003 [cited April 9 2003]. Available from http://www.windpowerindia.com/index.asp.

Chaurey, Akanksha. 2002. Fellow, TERI. New Delhi, December 8. Personal Interview

Chaurey, Akanksha, Malini Ranganathan, and Parimita Mohanty. 2002. Enhancing electricity access in rural areas through distributed generation based on renewable energy. New Delhi: Tata Energy Research Institute.

Das, T. K., and S. Banerjee. 1995. Energy technology choice in rural India. Energy 20 (7):683685. 
Drouilhet, S. 2001. Preparing an Existing Diesel Power Plant for a Wind Hybrid Retrofit: Lessons Learned in the Wales Alasks, Wind-Diesel Hybrid Power Project. Paper read at WindPower 2001, June 4-6, at Washington, DC.

Duffie, J., and W. Beckmann. 1991. Solar Engineering of Thermal Processes. 2nd ed. New York: Wiley \& Sons.

Dyer, Caroline. 2000. "Education for All" and the Rabaris of Kachchh, Western India. International Journal of Educational Research 33 (3):241-251.

EIA. 2002. Annual Energy Outlook 2002. Washington, DC: Energy Information Administration, US Department of Energy.

Flowers, L., Ian Baring-Gould, S. Drouilhet, J. Bianchi, and D. Corbus. 2000. Renewables for Sustainable Village Power. Paper read at WindPower 2000, at Palm Springs, CA.

GERC. 2000. Tariff Order No. 19 of 1999. Ahmedabad: Gujarat Electricity Regulatory Commission.

Gipe, P. 1999. Wind Energy Basics: A Guide to Small and Micro Wind Systems. White River Junction, VT: Chelsea Green.

Gregory, J., S. Silveira, A. Derrick, P. Cowley, C. Allinson, and O. Paish. 1997. Financing Renewable Energy Projects. London: Intermediate Technology Publications.

Gunaratne, L. 2002. Rural Energy Services: Best Practices. New Delhi: USAID.

Gupta, Shuchi, Krishna Mohan, Rajkumar Prasad, Sujata Gupta, and Arun Kansal. 1998. Solid waste management in India: options and opportunities. Resources, Conservation and Recycling 24 (2):137-154.

Hoff, T.E., H.J. Wenger, and B.K. Farmer. 1995. Distributed Generation: An Alternative to Electric Utility Investments in System Capacity. Energy Policy 24 (2):137-17.

Holland, Ray, Lahiru Perera, Teodoro Sanchez, and Rona Wilkinson. 2001. Decentralised rural electrification : Critical success factors and experiences of an NGO. Refocus 2 (6):2831.

Ibrahim, Muhammad, M. Anisuzzaman, S. Kumar, and S. C. Bhattacharya. 2002. Demonstration of PV micro-utility system for rural electrification. Solar Energy 72 (6):521-530.

Imhoff, J. 2003. Project Director, Auroville Energy. Auroville, January 9. Personal Interview

IREDA. 2003. Financing Norms. Indian Renewable Energy Development Agency 2003 [cited April 12 2003]. Available from http://ireda.nic.in/main_financingguidelines.htm.

Joshi, P.A. 1997. Wind Power: Potential as a Renewable Energy Resource in Gujarat State. Unpublished Thesis for the Faculty Development Program, Management Department, Indian Institute of Management, Ahmedabad.

Joshi, Rajendra. 2003. Managing Director, SAATH. Ahmedabad, January 5. Personal Interview

Kumar, M. Dinesh. 2000. Institutional framework for managing groundwater: A case study of community organisations in Gujarat, India. Water Policy 2 (6):423-432.

Kumar, S. 1999. Wind Energy - India Overview. Renewable Energy 16:961-964.

Lallament, Dominique. 2001. Opportunities for Decentralized Energy Services in Developing

Countries: a possible role for fuel cells? London: World Bank. Presentation Slides.

Lew, D, D. Corbus, R. Holz, L. Flowers, and J.A. McAllister. 1996. Analysis of Village Hybrid Systems in Chile. Golden, CO: National Renewable Energy Laboratory.

Lilienthal, P., L. Flowers, and C. Rossman. 1995. HOMER: The Hybrid Optimiazation Model for Electric Renewables. Paper read at Windpower 1995, March 27-30, at Washington, DC.

Malaviya, J. N., and S. P. Ranade. 1997. Potential of solar home-lighting system in rural western India. Solar Energy Materials and Solar Cells 47 (1-4):79-84.

McGowan, J., and S. Connors. 2000. Windpower: A Turn of the Century Review. Annual Review of Energy and the Environment. 
McGowan, J., and J. F. Manwell. 2000. Hybrid Wind/Photvoltaic/Diesel System Research at the University of Massachusetts. Wind Engineering 24 (2):119-126.

Mehta, Lyla. 2001. The Manufacture of Popular Perceptions of Scarcity: Dams and WaterRelated Narratives in Gujarat, India. World Development 29 (12):2025-2041.

MNES. 2002. Small Aerogenerators Hybrid Systems. MNES 2002 [cited October 23 2002]. Available from http://mnes.nic.in/frame.htm?majorprog.htm.

MoP. 2002. Distributed Generation Report. New Delhi: Ministry of Power.

Morris c, S. 2002. Professor, Indian Institute of Management. Ahmedabad, December 20. Personal Interview

Morris, Ellen. 1998. Analysis of Renewable Energy Retrofit Options to Existing Diesel MiniGrids. Singapore: APEC.

Natarajan, B. 2002. Senior Project Officer. New Delhi, December 9. Personal Interview

NCAER. 2002. West and Central India Human Development Report. Edited by N. C. o. A. E. Research. Delhi: Oxford University Press.

NREL. 2003. HOMER website. National Renewable Energy Laboratory 2003 [cited April 12 2003]. Available from www.nrel.gov/international/homer.

Pabla, A.S. 1997. Electric Power Distribution. 4th ed. New Delhi: Tata-McGraw-Hill.

Patil, S.B. 2003. Assistant Director, Gujarat Energy Development Agency. Vadodara, January.

PC. 2002. Annual Report (2001-02) on The Working of State Electricity Boards \& Electricity Departments. New Delhi: Planning Commission, GoI.

Petrie, E.M., H. L. Willis, and M. Takahashi. 2002. Distributed Power Generation in

Developing Countries. World Bank and ABB 2000 [cited October 12 2002]. Available from www.worldbank.org/html/fpd/em/distribution_abb.pdf.

PTIa. 2002. Wind energy major Suzlon to export $100 \mathrm{mw}$ turbines to US, China. Economic Times of India, October 8.

PTIa. 2003. Suzlon bags $\$ 22 \mathrm{mn}$ US order for wind turbines. Economic Times of India, February 23.

Rajsekhar, B., and A Mathur. 1999. Renewable based hybrid energy in backup and stand-alone systems. Asia Pacific Technology Monitor 16 (1):39-44.

Rajsekhar, B., F. Van Hulle, and J. C. Jansen. 1999. Indian wind energy programme: performance and future directions. Energy Policy 27 (11):669-678.

Ravindranath, N., and D.O. Hall. 1995. Biomass, Energy, and the Environment: A Developing Country Perspective from India. Oxford: Oxford University Press.

RBI. 2003. Annual Report. New Delhi: Reserve Bank of India.

Reuters. 2002. Wind power majors see big growth in India. Economic Times of India, October 9.

Richards, G. A., M. M. McMillian, R. S. Gemmen, W. A. Rogers, and S. R. Cully. 2001. Issues for low-emission, fuel-flexible power systems. Progress in Energy and Combustion Science 27 (2):141-169.

SAATH. 2002. Kadhir Earthquake Relief Project. Ahmedabad: SAATH.

Schmid, Aloisio Leoni, and Carlos A.A. Hoffmann. 2003. Replacing diesel by solar in the Amazon: short-term economic feasibility of PV-diesel hybrid systems. Energy Policy In Press, Corrected Proof.

Shah, Rakesh. 2003. Deputy Director, Gujarat Electricity Regulatory Commission. Ahmedabad, February 3. Interview

Sudha, P., and N. H. Ravindranath. 1999. Land availability and biomass production potential in India. Biomass and Bioenergy 16 (3):207-221.

TNN. 2003. SEBs to get $4 \%$ interest subsidy for rural loans. Econmic Times of India, March 14.

Tongia, Rahul, and Rangan Banerjee. 1998. Price of power in India. Energy Policy 26 (7):557575. 
UN. 1989. Energy Issues and Options for Developing Countries. New York: Taylor \& Francis. UNDP. 2003. Kachchh Ecology Fund. United Nations Development Program 2003 [cited April 5 2003]. Available from http://www.undpquakerehab.org/kef/.

van Beukering, P., M. Sehker, R. Gerlagh, and V. Kumar. 1999. Analysing Urban Solid Waste in Developing Countires: a Perspective on Bangalore, India. London: Intenational Institute for Enviornment and Development.

WB. 2001. India Power Supply to Agriculture. Washington, D.C.: World Bank.

WEC. 2000. Renewable Energy in South Asia: Status and Prospects. London: World Energy Council.

Yang, Ming. 2003. China's rural electrification and poverty reduction. Energy Policy 31

(3):283-295. 